Article

\title{
Initiation and Organization Mechanisms of Mesoscale Convective Systems in a Warm-Sector Torrential Rainfall Event over Beijing
}

\author{
Lei Yin ${ }^{1,2}$, Jiahua Mao ${ }^{1,2, *}$, Fan Ping ${ }^{2,3}{ }^{\mathbb{C}}$, Xiaofan $\mathrm{Li}^{4}$ and Ning Wang ${ }^{5}$ \\ 1 Zhejiang Early Warning Center, Zhejiang Meteorological Bureau, Hangzhou 310002, China; \\ yinlei@mail.iap.ac.cn \\ 2 Key Laboratory of Cloud-Precipitation Physics and Severe Storms, Institute of Atmospheric Physics, \\ Chinese Academy of Sciences, Beijing 100029, China; pingf@mail.iap.ac.cn \\ 3 School of Remote Sensing \& Geomatics Engineering, \\ Nanjing University of Information Science \& Technology, Nanjing 210044, China \\ 4 Department of Earth Sciences, Zhejiang University, Hangzhou 310027, China; xiaofanli@zju.edu.cn \\ 5 Zhejiang Institute of Meteorological Sciences, Zhejiang Meteorological Bureau, Hangzhou 310002, China; \\ ningwangll@163.com \\ * Correspondence: maojh90@163.com
}

Received: 6 July 2020; Accepted: 25 August 2020; Published: 4 September 2020

check for updates

\begin{abstract}
A torrential rainfall that occurred in Beijing during the period of 21-22 July 2012 is simulated by the Weather Research and Forecasting Model in order to investigate the probable mechanisms for the initiation and organization of warm-sector mesoscale convective systems (MCSs). The simulated results show that the cyclone, which formed in Hetao area, Inner Mongolia and moved eastward slowly, played a key role in the formation and development of warm-sector precipitation, although the favorable atmospheric environment and the configuration of weather systems are also important, which caused the trigger and organization of convective cells along Taihang Mountains. It is the interaction of the local terrain convergence line and the southerly airflows of Hetao cyclone that cause the continuous trigger of convective cells along Taihang Mountains. While, the triggers of convective cells in the plains are caused by the gravity waves, which is related to the development and eastward movement of Hetao cyclone. It must be pointed out that the merging and coupling between the cells that triggered in Taihang Mountains and moved southwesterly and the cells that triggered in plains and moved northeasterly are the key factors for the formation and development of MCSs during the warm-sector precipitation. In addition, the back-building processes and the cold pool forcing are also important for the formation and development of MCSs in this study.
\end{abstract}

Keywords: warm-sector precipitation; convective initiation; convective organization

\section{Introduction}

Warm-sector torrential rain (WSTR), which occurs in warm and moist air masses with small thermal gradients located in the warm section of a depression or cyclone (Nozumi and Arakawa, 1968 [1]; Kingsmill et al., 2006 [2]) is one of the most important precipitation types in China (Zhang et al., 2013 [3]; Wen et al., 2015 [4]; Zhong et al., 2015 [5]; Mao et al., 2018a [6]). Compared with frontal precipitation, WSTR can generate much greater amounts of rainfall, and the precipitation echoes of the warm sector often have some distinct characteristics, such as quasi-linearity, quasi-stationarity, and back-building (Nozumi and Arakawa, 1968 [1]; Schumacher and Johnson, 2005 [7]; Zhong et al., 2014 [8]; Kim et al., 2019 [9]). The mesoscale convective systems (MCSs) that produce WSTR are usually triggered locally, develop through convective organization, and can cause strong precipitation in a 
short time. In recent years, extreme precipitation events like WSTRs have occurred more frequently in China against the background of global warming, causing considerable losses of lives and property, and thus the prediction of WSTR events is a key challenge.

Studies on WSTR stretch back to the last century, most of which focused on analysis of the synoptic environment of MCSs. Browning et al. (1974) [10] studied warm-sector precipitation in South Wales during the winter season, and found that the differential of temperature advection in the strong baroclinic zone ahead of the cold front led to the potential instability in the mid-troposphere and triggered the strong local precipitation. Maddox et al. (1979) [11] analyzed 151 extreme convective precipitation cases in the United States, and found that convection usually occurred in the area with a ridge in the mid-troposphere and high humidity at the surface. A meso- $\alpha$-scale trough was found to be conducive to the initiation and organization of MCSs.

At present, studies on the initiation and organization mechanism of MCSs are mainly based on multi-source observations and cloud-resolving numerical simulations. By using the observational data from TiMREX (Terrain-influenced Monsoon Rainfall Experiment), Xu et al. (2012) [12] found that MCSs are triggered at the boundaries of the surface cold pool and low-level jet stream. Wang et al. (2014) [13] used the intensive observations from SCMREX (the Southern China Monsoon Rainfall Experiment) and pointed out that convective systems that produce precipitation are triggered by a southeasterly low-level jet over the coastal topography in the early stage. Su and Zhai (2017) [14] studied a heavy precipitation process in eastern China based on observations and cloud-resolving simulation results, and found the combination of a convective convergence line and gravity waves was the main triggering mechanism of these convective systems. In fact, the initiation and organization of MCSs are also related to the development and movement of mesoscale vortices. Research conducted by Schumacher and Johnson $(2008,2009)[15,16]$ revealed the interaction of a low-level jet, gravity waves, and a cold pool at the surface with the mid-level vortex to be the main reason for the initiation and organization of convective systems. Xu et al. (2017) [17] simulated a Mei-yu front torrential rainfall event in eastern China with a cloud-resolving model. It was found that during the dissipating stage of the MCSs, the downward movement of the mid-level vortex increased the potential vorticity in the lower troposphere, which coupled with the low-level jet and triggered the secondary convective system on the southeast side of the mesoscale convective vortex.

Despite the above findings, the initiation and organization of MCSs during warm-sector precipitation still needs to be studied further, so as to improve its forecast skill. In the present study, version 4 of the Weather Research and Forecasting Model (WRF) was used to reproduce the warm-sector precipitation process during the torrential rainstorm that took place in Beijing on 21 July 2012. Then, based on the simulation, the initiation and organization mechanism of the convective systems that produced the warm-sector rain was examined in detail.

The remainder of the paper is organized as follows: Section 2 provides an overview of the extreme precipitation process and an analysis of the synoptic conditions. The configuration of the numerical model and verification of the model results are reported in Section 3. Section 4 discusses the initiation and organization mechanism of the MCSs. Lastly, a summary and further discussion are presented in Section 5 .

\section{Case Overview and Synoptic Analysis}

\subsection{Case Overview}

An extremely severe rainfall event occurred in Beijing, which is located in the northern part of the North China Plain and surrounded by the Yan Mountains in the north and Taihang Mountains in the southwest (Figure 1), during the period of 21-22 July 2012 (also referred to as the '721' rainfall event). The record-breaking rainfall event had a regional average 24-h precipitation amount of $190.3 \mathrm{~mm}$ in the urban area and a 24-h accumulated amount of $460 \mathrm{~mm}$ in Fangshan District (solid star in Figure 1) 
(Zhang et al., 2013) [3]. The maximum hourly precipitation reached $100.3 \mathrm{~mm}$ in Pinggu District (hollow star in Figure 1) in the southwest of the Yan Mountains (Wang et al., 2015) [18].

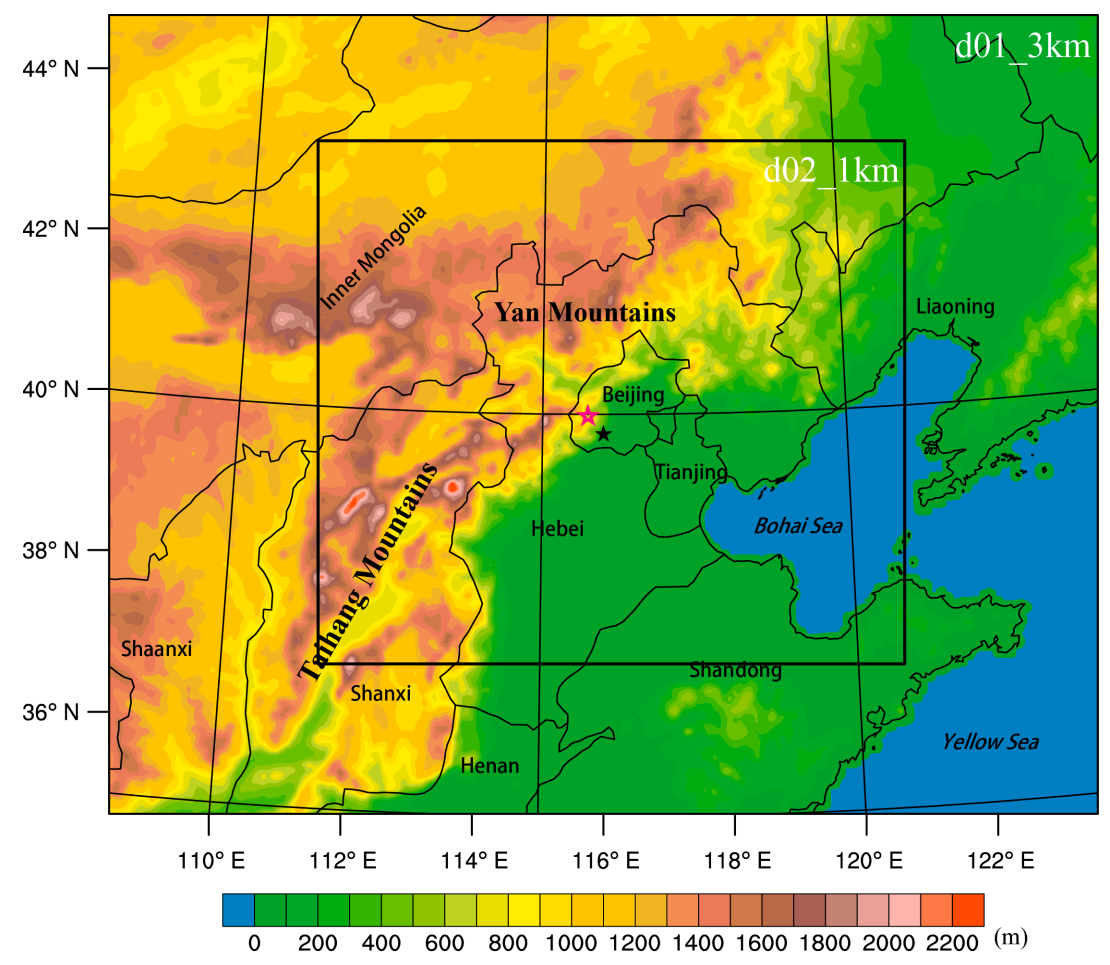

Figure 1. Topography (shaded) diagram in the simulation domains (d01, d02). The Taihang Mountains and Yan Mountains (bold font) and some provinces of China (regular font) over the domains are labeled. Mentougou District and Fangshan District of Beijing are marked separately by magenta and black pentagrams denoting its downtown area.

\subsection{Synoptic Analysis of the Torrential Rainfall against the Background of Hetao Cyclone}

There have been numerous studies on the multi-scale meteorological environment of the ' $721^{\prime}$ torrential rainfall event in Beijing. Mao et al. (2018b) [19] pointed out that this heavy rainstorm occurred under a favorable configuration of synoptic conditions, including the divergence associated with the upper-level jet at $200 \mathrm{hPa}$, two blocking high pressures at $500 \mathrm{hPa}$, and the long-distance transport of the water vapor of Typhoon Vicente at $850 \mathrm{hPa}$. Our own research reveals that the occurrence of the ' $721^{\prime}$ ' rainstorm was mainly related to the movement and enhancement of a cyclone in Hetao, Inner Mongolia, which was mainly located at $700 \mathrm{hPa}$. In order to understand the environmental conditions associated with the Hetao cyclone, the reanalysis data from ECMWF were used to analyze the temporal and spatial distribution of the pressure, temperature, and humidity field of the cyclone. Figure 2 is a synthetic field of geopotential height at $700 \mathrm{hPa}$, equivalent potential temperature, water vapor flux, and its divergence. It seems from Figure 2a1 that the Hetao vortex was located at around $\left(39^{\circ} \mathrm{N}, 110^{\circ} \mathrm{E}\right)$ at $0000 \mathrm{UTC} 21$ July 2012, with a central value of $3060 \mathrm{gpm}$. Beijing was controlled by southerly winds at this moment. In view of the moisture field (Figure 2a2), water vapor was mainly transported by the flow on the south side of the cyclone, and converged in the center of the vortex, forming a strong convergence center of water vapor. Six hours later (Figure 2b1), the Hetao cyclone moved eastwards to $112^{\circ} \mathrm{E}$, with a central value of $3050 \mathrm{gpm}$. The tongue of high potential temperature also shifted to Beijing, and Beijing was dominated by southwesterly winds. In addition, the two transport channels of water vapor on the south side of the Hetao cyclone merged, and the convergence center of water vapor also moved to Beijing. It should be pointed out that the three centers of the cyclone, high potential temperature, and water vapor convergence coincided in the Beijing area at 1200 UTC 21 July (Figure 2c1,c2), which meant that the warm-sector precipitation developed to a peak stage. 

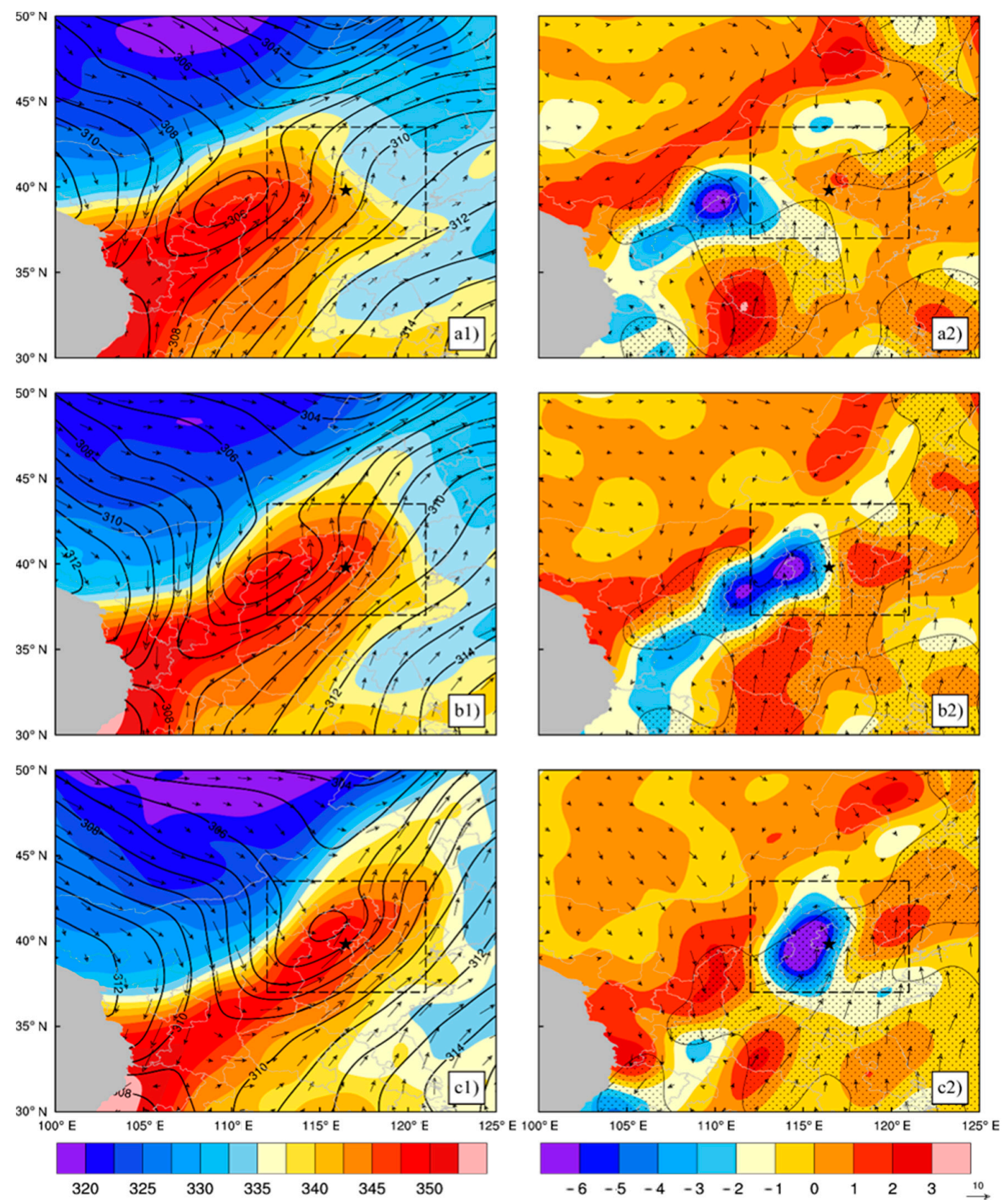

Figure 2. (a1-c1) Observed equivalent temperature (shaded, units: K), geopotential height (contours, units: $10 \mathrm{gpm}$ ), and wind field (vector arrows, units: $\mathrm{m} \mathrm{s}^{-1}$ ) at $700 \mathrm{hPa}$. (a2-c2) Observed water vapor flux divergence (shaded, units: $\left.\mathrm{g}\left(\mathrm{s} \cdot \mathrm{cm}^{-2} \cdot \mathrm{hPa}^{-1}\right)^{-1}\right)$, water vapor flux (dotted, units: $\mathrm{g} \mathrm{s}^{-1} \mathrm{hPa}^{-1} \mathrm{~cm}^{-1}$ ), and wind field (vector arrows, units: $\mathrm{m} \mathrm{s}^{-1}$ ) at $850 \mathrm{hPa}$. The positive (negative) value of water vapor flux divergence means the divergence (convergence) of water vapor. The results are valid at 0000 UTC (a1,a2), 0600 UTC (b1,b2), and 1200 UTC (c1,c2) 21 July 2012. The location of Beijing is marked with the black pentagram. The black dotted box denotes the area of domain 2 .

\section{Model Configuration and Verification}

\subsection{Model Configuration}

In this study, version 4.0 of the WRF model-a three-dimensional, fully compressible and non-hydrostatic mesoscale model developed by NCEP/NCAR - was used to simulate the warm-sector precipitation process during the ' 721 ' rainstorm in Beijing. Reanalysis data from ECMWF, with a 
horizontal resolution of $0.5^{\circ}$, were chosen as the initial and boundary conditions. The model was integrated for $12 \mathrm{~h}$ from 0000 UTC to 1200 UTC 21 July, with a time step of $6 \mathrm{~s}$. The model was designed with two domains and one-way nesting (Figure 1). The first domain had $421 \times 331$ grid points with a grid spacing of $3 \mathrm{~km}$, and the second domain had $721 \times 721$ points with a spacing of $1 \mathrm{~km}$. In the vertical direction, there were 81 layers with a sigma-pressure hybrid coordinate, and the pressure of the model top was $50 \mathrm{hPa}$. The cumulus parameterization scheme was not used in this study because of the cloud-scale resolution. The other physical parameterization schemes included the Morrison two-moment microphysical scheme, the YSU boundary layer scheme, the Noah land surface scheme, the RRTM longwave radiation scheme, and the Dudhia shortwave radiation scheme. The model results were outputted every $1 \mathrm{~min}$.

\subsection{Model Verification}

The simulated fields, including the accumulated rainfall at the surface and radar reflectivity, were verified with the observed precipitation and Doppler radar data from the China Meteorological Administration. The observed precipitation data were a merged product of automatic weather stations in China and CMORPH satellite data, with a temporal resolution of $1 \mathrm{~h}$ and horizontal resolution of $0.1^{\circ} \times 0.1^{\circ}$. The Doppler radar data were obtained every $6 \mathrm{~min}$ and had a resolution of $0.01^{\circ} \times 0.01^{\circ}$.

Figure $3 a 1-\mathrm{c} 1$ shows the observed and simulated precipitation that accumulated during the first $6 \mathrm{~h}$ of the warm-sector precipitation stage (from 0000 to 0600 UTC 21 July). From Figure 3a1, several observed rainfall centers, with 6-hourly precipitation amounts larger than $50 \mathrm{~mm}$, were located around the center of the Hetao cyclone (near $\left.39.5^{\circ} \mathrm{N}\right)$. The strong rainfall center in front of the cyclone $\left(39.5^{\circ} \mathrm{N}\right.$, $115^{\circ} \mathrm{E}$ ) had reached Fangshan District in the southwest of Beijing city. From the simulated precipitation with a resolution of $3 \mathrm{~km}$ (Figure $3 \mathrm{~b} 1$ ), the observed rainfall centers around the center of the cyclone were generally reproduced. The distribution of the rain band north of $38^{\circ} \mathrm{N}$ was consistent with the observation, while it was stronger than observed south of $38^{\circ} \mathrm{N}$. The rainfall center around $115^{\circ} \mathrm{E}$ also reached Beijing, although its intensity was stronger than observed. From the results at finer resolution (Figure 3c1), the patterns of precipitation in the inner domain were basically the same as those in the outer domain, but depicted in more detail. During the next $6 \mathrm{~h}$ (from 0600 to 1200 UTC 21 July) (Figure 3a2-c2), the observed heavy rainfall centers moved northeastwards along with the vortex, and the whole city of Beijing was within the scope of torrential rain (Figure 3a2). Extremely torrential rainfall, with 6-hourly cumulative amounts greater than $250 \mathrm{~mm}$, occurred in Fangshan District, southwest Beijing. Figure $3 b 2$ shows the simulation results at the $3 \mathrm{~km}$ resolution. For the rain band of $100 \mathrm{~mm}$, the model overestimated its intensity in the south of the rain band, but underestimated it in the north of the rain band. For the centers of extremely heavy rain $(>250 \mathrm{~mm})$, the simulation was basically consistent with the observation, but had a wider range. The 1-km resolution results were generally the same as the results at $3 \mathrm{~km}$ (Figure 3c2).

Figure 4 shows the time series of observed and simulated hourly rainfall amount averaged over the black box in Figure 3a1. The dotted line in the figure distinguishes the warm sector precipitation and the cold front precipitation stage. It can be seen that simulation basically reproduces the evolutionary trend of hourly precipitation. At 1200 UTC, the average hourly precipitation reached to the maximum of $20 \mathrm{~mm} \mathrm{~h}^{-1}$ and the simulation matched well with observation. Moreover, the model had better performance in the simulation of warm sector precipitation than that of cold front precipitation, which was slightly overestimated. Table 1 gives the correlation coefficient and the Root Mean Square Error (RMSE) of the hourly rainfall amount. It was seen that the correlation coefficient in warm-sector precipitation (WSP) stage was higher than that in cold front precipitation stage (CFP), while RMSE was lower than that in CFP. Therefore, the simulation data can be used to analyze the formation mechanism of precipitation in the warm sector. 

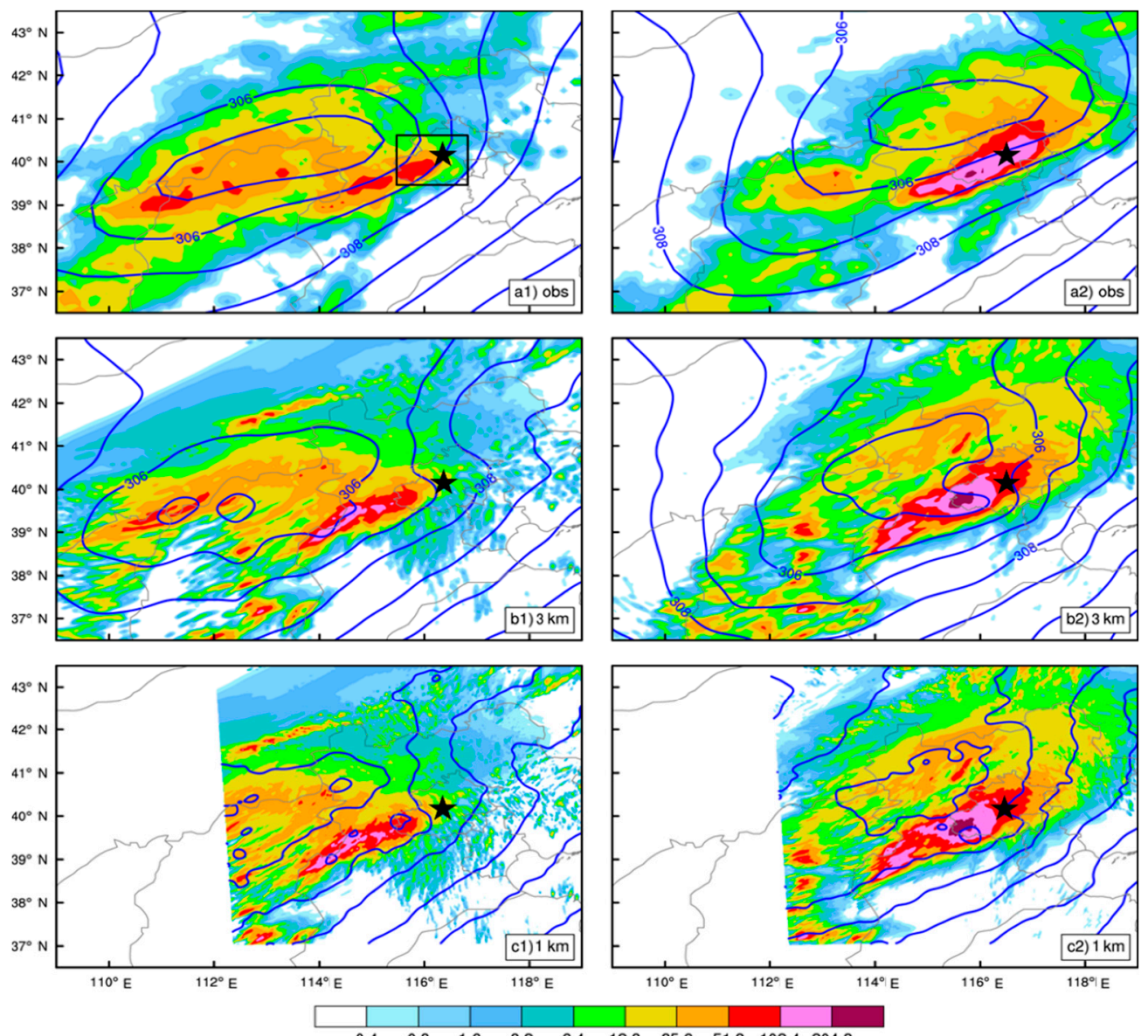

Figure 3. The observed (a1,a2) and 3-km simulated (b1,b2) and 1-km simulated (c1,c2) 6-h cumulative precipitation (shaded, units: $\mathrm{mm}$ ) and the geopotential height (blue contours, units: $10 \mathrm{gpm}$ ) at $700 \mathrm{hPa}$ during the period 0000-0600 UTC (a1-c1) and 0600-1200 UTC (a2-c2) 21 July 2012. The black star denotes the location of Beijing.

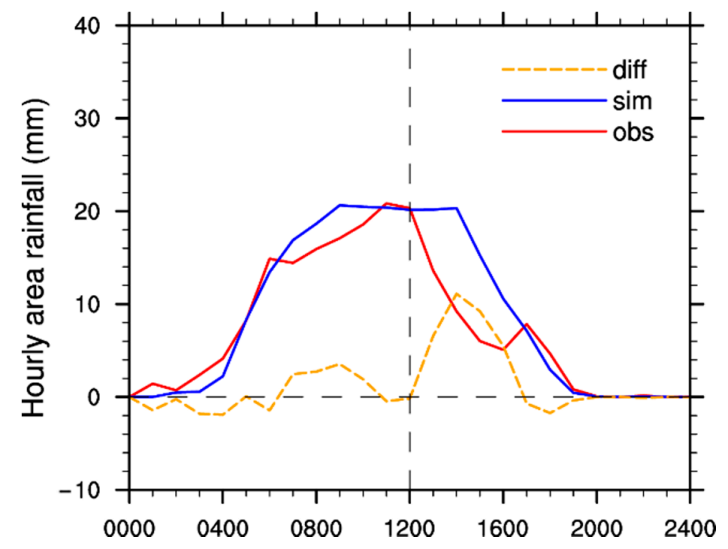

Figure 4. Time series of the observed (red line) and simulated (blue line) mean hourly rainfall amount. Yellow line represents the difference between simulation and observation. Regional averaging is performed over the black box in Figure 3a1.

Table 1. Statistical results of the observed and simulated hourly rainfall amount.

\begin{tabular}{lccc}
\hline & WSP & CFP & ALL \\
\hline CORR & 0.985 & 0.885 & 0.925 \\
RMSE & 1.777 & 4.686 & 3.614 \\
\hline
\end{tabular}


Figure 5 shows the observed and simulated radar echo at the resolution of $1 \mathrm{~km}$. Yu (2012) [20] pointed out that warm-sector precipitation in Beijing is mainly produced by four meso- $\beta$-scale convective systems, which pass through Beijing one after another. In the present study, the radar observations revealed that four convective systems (labeled A, B, C, and D in Figure 5a1-d1) initiated at the eastern foot of the Taihang Mountains at around $\left(39^{\circ} \mathrm{N}, 114.5^{\circ} \mathrm{E}\right)$, and then moved along the mountains from southwest to northeast. The propagation of the convective systems showed obvious back-building and train-effect characteristics. Figure $5 \mathrm{a} 2-\mathrm{d} 2$ shows the simulated radar reflectivity. It seems that the initiation and propagation processes of the four convective systems were well reproduced by the model, although the intensity of radar echoes was slightly overestimated. In addition, observations showed that two types of organizational modes existed for systems A, B, and C: the organization of convective cells themselves, and the organization of linear convective systems in different directions (Figure 5c1,d1). The two organizational modes were well reproduced by WRF (Figure 5a2-d2). From Figure 5b2, two MCSs, which were oriented in the southwest-northeast and southeast-northwest directions, respectively, organized and developed in the southwest of Beijing $\left(39.5^{\circ} \mathrm{N}, 115.2^{\circ} \mathrm{E}\right)$.

In short, the warm-sector precipitation in Beijing was well reproduced by the cloud-resolving WRF model with horizontal resolutions of 3 and $1 \mathrm{~km}$ in the outer and inner domains, respectively. In particular, the triggering, propagation, and organization processes of the MCSs that produced the extreme rain were clearly simulated.
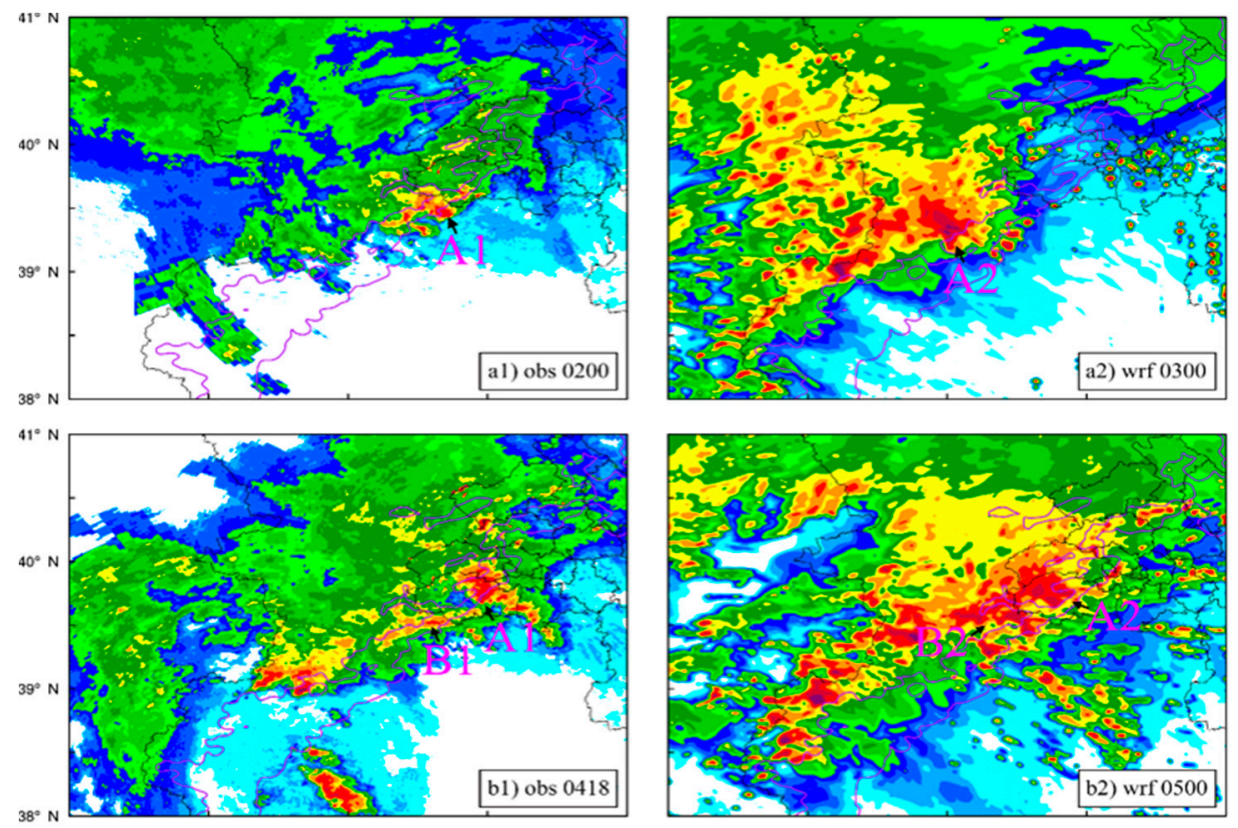

Figure 5. Cont. 

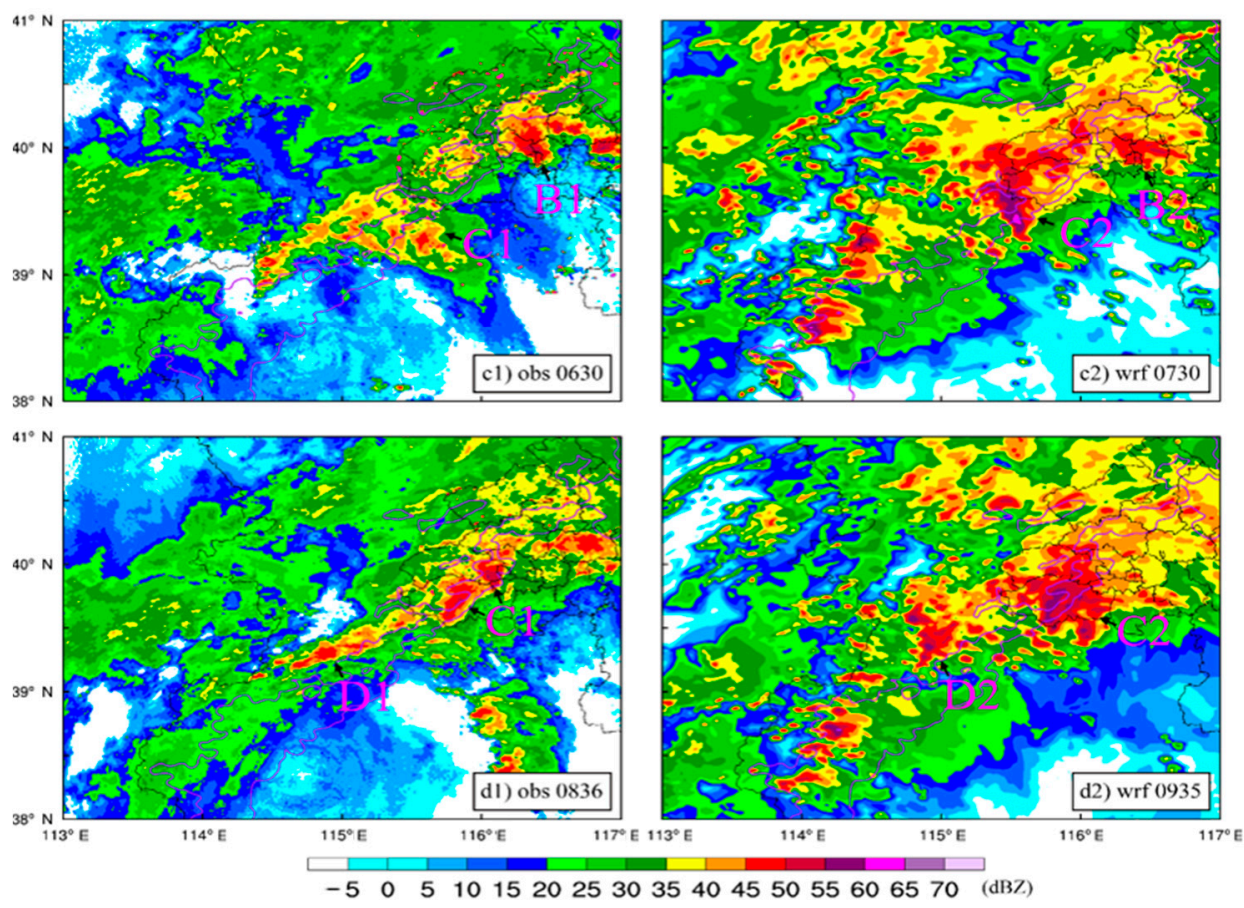

Figure 5. (a1-d1) Observed composite radar reflectivity (shaded, units: dBZ) at 0200, 0418, 0630, and 0836 UTC 21 July 2012, respectively. The black contours are terrain height (units: m). (a2-d2) As in (a1-d1) but for the simulated results, which are valid at 0300, 0500, 0730, and 0935 UTC 21 July 2012. The labels "A1/A2", "B1/B2", "C1/C2", and "D1/D2" denote the four main mesoscale convective systems (MCSs) (A, B, C, and D), respectively.

\section{Initiation and Organization of Convective Cells during the Warm-Sector Precipitation}

Both observational and numerical experiment results show that Beijing underwent four heavy precipitation processes during the warm-sector precipitation stage, which were caused by four convective systems passing through Beijing one after another. Among them, the heaviest rainfall was produced by the third convective system. Importantly, the triggering mechanism of convective cells differed in plain and mountain areas. During the warm-sector precipitation stage, there not only existed the organization of convective cells, but also the organization of wave trains. The corresponding analysis and discussion are reported in the following parts of the paper.

\subsection{Initiation of Convective Cells over the Plains}

Observations showed that the third convective system (MCS-C), which caused the heaviest rainfall in Beijing, was initiated over the plains and developed through organization. In this section, first, the simulated data with a high spatial and temporal resolution were used to examine the triggering process of MCS-C in detail. Then, the effects of the Hetao cyclone on the development of MCS-C were analyzed. Lastly, a probable mechanism of the triggering of the convective cells over the plains is presented.

\subsubsection{Characteristics of the Initiation Process of MCS-C}

Figure 6 presents the synthetic field of radar reflectivity and wind at $700 \mathrm{hPa}$ during the triggering period of MCS-C. At 0438 UTC 21 July (Figure 6a), strong convective systems were mainly located over the Taihang Mountains, and a block of convection (labeled ' $a$ ') was initiated over the plains to the southeast of Taihang Mountains-an area controlled by southwesterly airflow. At 0450 UTC (Figure 6b), the convective block 'a' intensified as a convective cell. After 6 min (Figure 6c), a new block of convection (' $b$ ') was initiated on the left-hand side of cell ' $a$ '. At 0505 UTC (Figure 6d), the convective block ' $b$ ' enhanced rapidly as a convective cell, and then both of them moved northwards. 


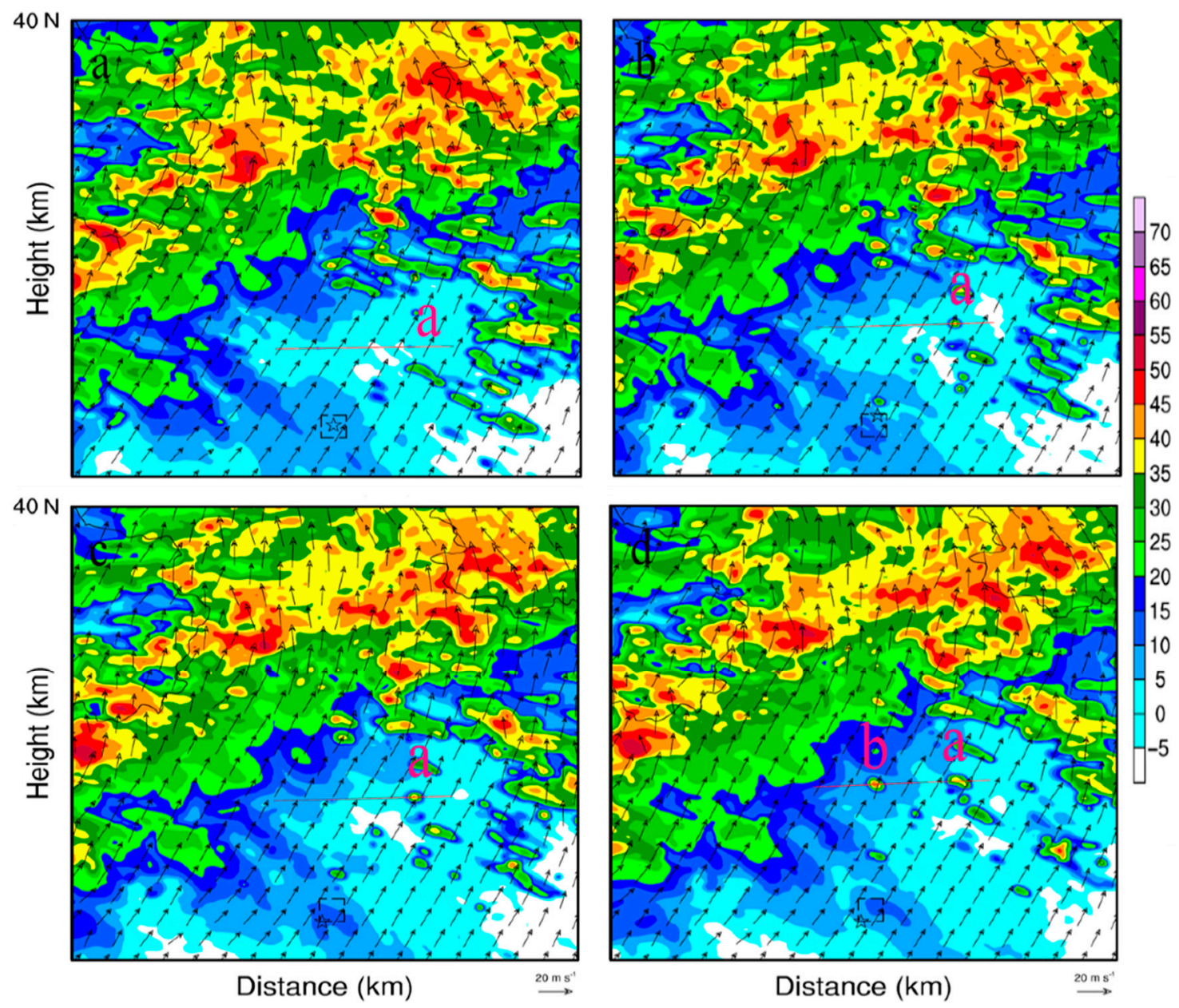

Figure 6. (a-d) Simulated composite radar reflectivity (shaded, unit: dBZ) and the wind field (vector arrows, units: $\mathrm{m} \mathrm{s}^{-1}$ ) at $700 \mathrm{hPa}$ at 0438, 0450, 0456, and 0505 UTC 21 July 2012, respectively. The letters, " $a$ " and " $b$ " denote convective cells over the plains.

Figure 7 shows vertical cross sections of the radar reflectivity and wind field along the magenta line in Figure 6. Convective cell ' $a$ ' was triggered at the height of $2.3 \mathrm{~km}$ above the lifting condensation level (LCL, gray dotted line) at 0438 UTC (Figure 7a). The planetary boundary layer height (PBLH, black dotted line) was located above the LCL and level of free convection (LFC, pink solid line). The updraft branch of the wind field corresponded with cell ' $a$ '. At 0450 UTC (Figure 7b), cell ' $a$ ' intensified significantly, with the radar reflectivity increasing to $35 \mathrm{dBZ}$ and the updraft reaching the height of $4 \mathrm{~km}$. Six minutes later (Figure 7c), the radar echo of cell ' $a$ ' reached the ground with the intensity increasing to $40 \mathrm{dBZ}$, and the PBLH and LCL decreased significantly. Cell ' $b$ ' was initiated on the left-hand side of cell ' $a$ ' at the height of $2.5 \mathrm{~km}$. From the wind field, the updraft of cell ' $b$ ' had reached $4.5 \mathrm{~km}$, which meant that cell ' $b$ ' had a better condition for development than cell ' $a$ '. At 0505 UTC (Figure 7d), cell ' $b$ ' intensified rapidly, with the radar reflectivity increasing to $40 \mathrm{dBZ}$ and the updraft reaching $6 \mathrm{~km}$. However, the updraft of cell 'a' started to weaken and the downdraft was formed at the height of $2 \mathrm{~km}$. 

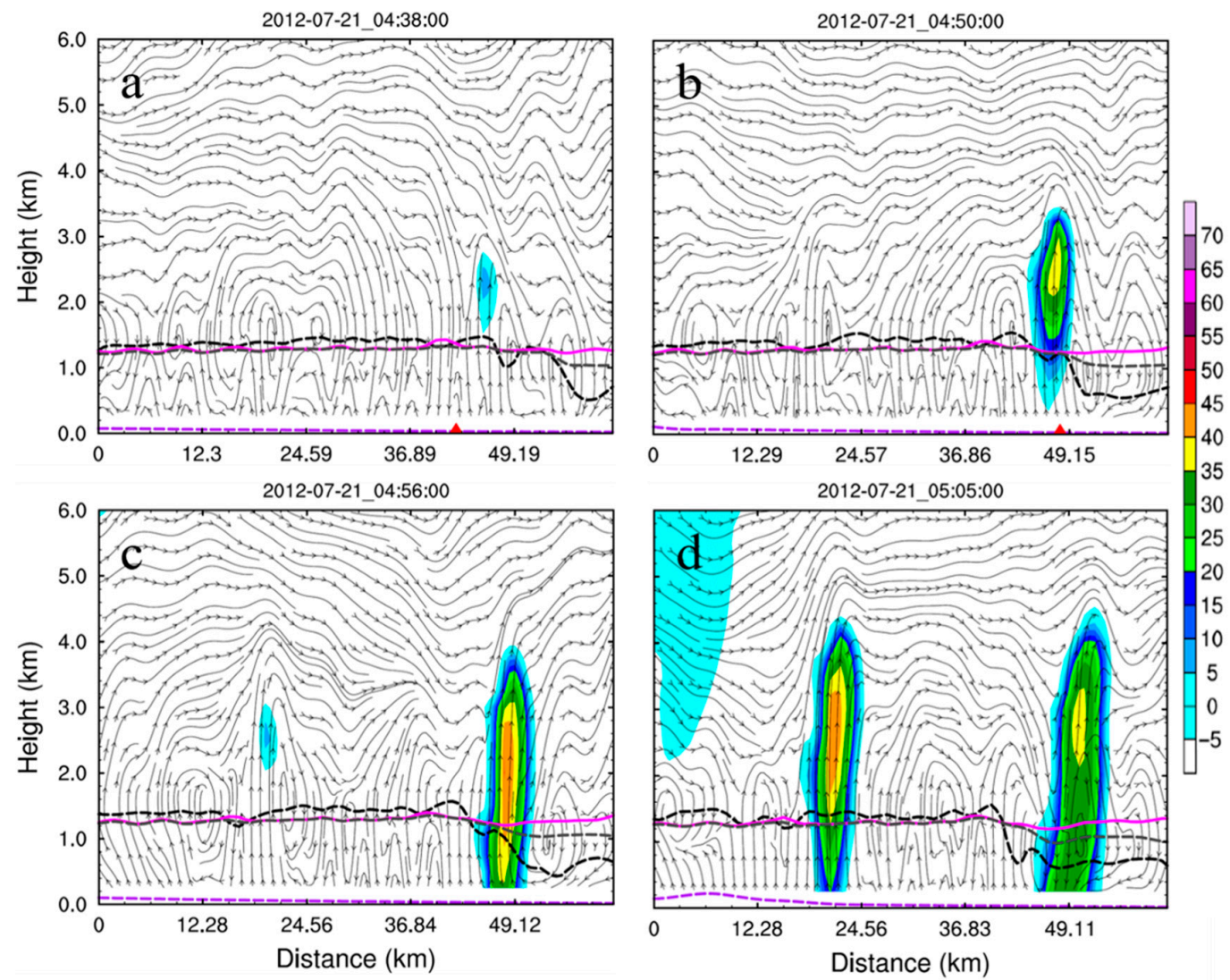

Figure 7. (a-d) Vertical cross sections of the simulated composite radar reflectivity (shaded, units: $\mathrm{dBZ}$ ), the wind field (streamlines, units: $\mathrm{m} \mathrm{s}^{-1}$ ), the lifting condensation level (LCL) (gray dotted line), the planetary boundary layer height (PBLH) (black dotted line), and the level of free convection (LFC) (magenta solid line) at 0438, 0450, 0456, and 0505 UTC 21 July 2012, respectively. The locations of cross sections were denoted by the magenta lines given in Figure 6.

\subsubsection{Role of Hetao Cyclone in the Initiation of MCS-C}

It is known that the development and movement of the Hetao cyclone had a considerable impact on the occurrence of the '721' rainstorm in Beijing. Here, in this part, the influence of the Hetao vortex on the initiation and development of MCS-C is discussed. From Figure 8a, the line of $3060 \mathrm{gpm}$ at $700 \mathrm{hPa}$ moved successively through the latitudes $113.65^{\circ} \mathrm{E}, 115.2^{\circ} \mathrm{E}, 115.9^{\circ} \mathrm{E}$, and $116.4^{\circ} \mathrm{E}$ at the time of 0400, 0600, 0800, and 1000 UTC, respectively. Figure 8b shows the vertical profiles of relative vertical vorticity from 0400 to 1000 UTC. The maximum vorticity was located near the surface at 0200 UTC 21 July. Two hours later, the center of vorticity moved to the upper troposphere at the height of $6.8 \mathrm{~km}$. At $0600 \mathrm{UTC}$, the upper-level vorticity decreased while the low-level vorticity increased, and the center of vorticity was at the height of $2 \mathrm{~km}$ at 0800 UTC. At 1000 UTC, the maximum vorticity appeared in the lower troposphere at $1.3 \mathrm{~km}$. Therefore, the relative vertical vorticity changed with the eastward movement of the Hetao cyclone. The vertical vorticity increased in the upper troposphere first, and then increased in the lower troposphere.

As MCS-C was initially formed, the radar echo was mainly located in the southeastern quadrant of the Hetao vortex in the southwest-northeast direction (Figure 8a). Based on the low-pass, band-pass and high-pass filtering methods proposed by Barens (1973) [21], the large-scale, meso-scale, and small-scale components of the wind field at the triggering time could be obtained, respectively. In the large-scale component field (Figure 8d), the low levels of the troposphere were controlled by southeasterly winds, with the wind speed decreasing from south to north and the vorticity decreasing from west to east. In the meso-scale field (Figure 8e), there was a closed center of vorticity near $\left(39.67^{\circ} \mathrm{N}, 113.5^{\circ} \mathrm{E}\right)$, which corresponded to the Hetao cyclone. The southeastern quadrant of the Hetao cyclone was located over 
the plains, where the wind speed was relatively high. Meanwhile, the center of the cyclone was located over the Taihang Mountains, with low wind speed. In the small-scale component field (Figure 8f), the centers of the wind field and vorticity corresponded with the location of MCS-C, although they were distributed dispersed.
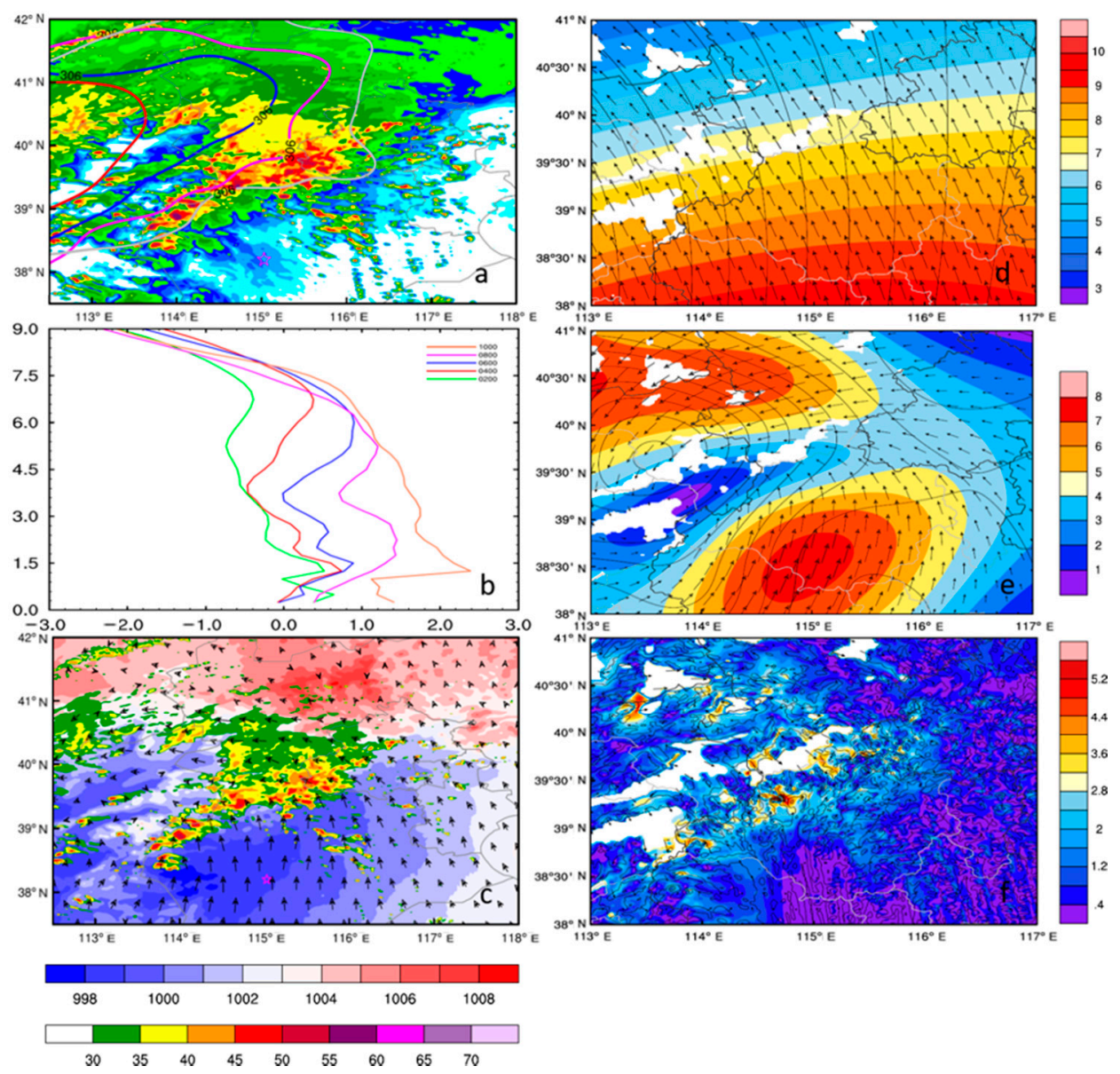

Figure 8. (a) Simulated composite radar reflectivity (shaded, units: dBZ) at the initiation time of MCS-C. The red, blue, and magenta lines represent the 306 (units:10 gpm) feature line of Hetao vortex at $700 \mathrm{hPa}$ at 0400, 0600, and 0800 UTC, respectively. (b) Area-averaged vertical profile of the 306 feature lines (units: $10 \mathrm{gpm}$ ) of Hetao vortex. (c) Simulated composite radar reflectivity (shaded, units: $\geq 35 \mathrm{dBZ}$ ), the sea level pressure (red and blue shading, units: Pa), and the 10-m wind field (arrows) at the initiation time of MCS-C. The initiation location of the first convective cell over the plains is marked with the magenta pentagram. (d-f) The large-scale, meso-scale, and small-scale component of wind field at the initiation time MCS-C, which were extracted by Barens' (1973) low-pass, band-pass, and high-pass filtering methods, respectively. All of them include the wind speed field (shaded, units: $\mathrm{m} \mathrm{s}^{-1}$ ), the vorticity field (contours, units: $\mathrm{s}^{-1}$ ), and the wind field (vector arrows, units: $\mathrm{m} \mathrm{s}^{-1}$ ).

In short, the southwesterly airflow in the southeast quadrant of the Hetao cyclone enhanced the large-scale southerly wind over the plains, which carried much warm and moist air to the region. The water vapor and potential instability energy carried by the southerly wind accumulated in the plains region and provided favorable conditions for the initiation of the convective systems.

\subsubsection{Initiation Mechanism of Convective Cells in the Plain Region}

The possible mechanism for the triggering of convective cells in the plain region is further explored in this section. The Hetao cyclone was a strong low-pressure system, and its eastward movement may cause the change in pressure in the mid-lower troposphere. Figure $8 \mathrm{c}$ shows the horizontal distribution 
of the radar echo and sea level pressure at the triggering time of MCS-C. It can be seen that there were several south-north wave-like trains of radar echoes around the area of $\left(38.5^{\circ} \mathrm{N}, 115.5^{\circ} \mathrm{E}\right)$, which were approximately parallel to the contours of sea level pressure. From the temporal evolution of the sea level pressure (not shown), the sea level pressure field over the plains propagated from west to east, showing wave-like propagation features. The change of pressure in the lower troposphere can also be seen from Figure 9c. It was shown that the sea level pressure decreased with time because of the influence of Hetao cyclone. At the location where convection is initiated over the plains (PCI, blue line), the sea level pressure showed significant fluctuation characteristics, while it is not obvious in the plain where no convection is initiated (NCI, orange line), which further indicated that the triggering of convection in the plain was closely related to the pressure fluctuation in the lower atmosphere. The rapid decrease of sea level pressure in mountain areas (MCI, red line) may be related to the triggering of convection in the mountains. In order to further examine the fluctuations in the lower atmosphere, the horizontal distribution of vertical velocity at $1 \mathrm{~km}$ was shown in Figure $9 \mathrm{a}$. It can be seen that the vertical velocity shows obvious positive and negative change in the plain area. From the vertical cross section (Figure 9b), the positive and negative distribution of vertical velocity was concentrated below $1.5 \mathrm{~km}$. Figure 9d shows the time-distance diagram of vertical velocity at $1 \mathrm{~km}$. It can be seen that the vertical velocity is positive and negative distributed, and propagated from southwest to northeast.
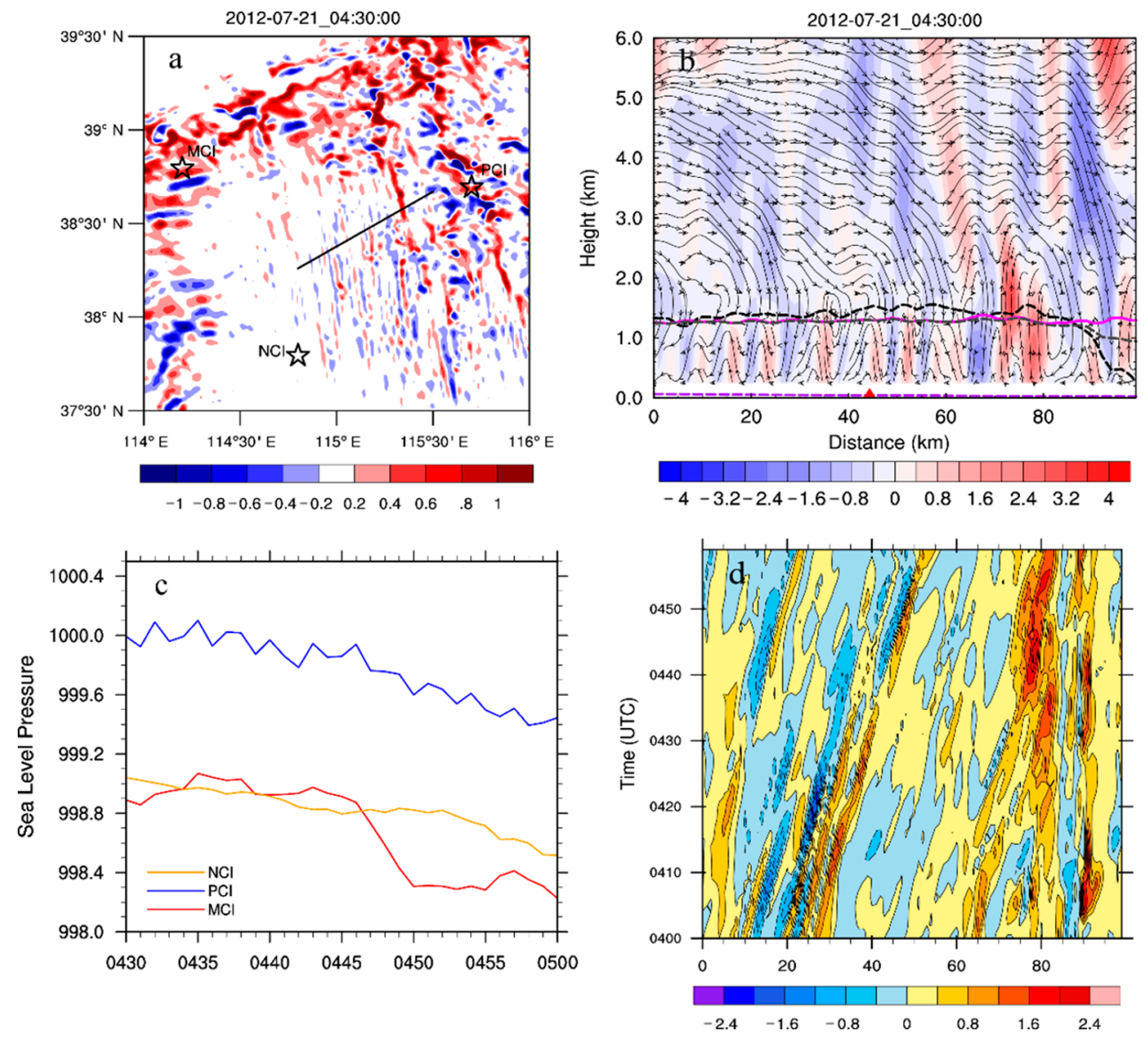

Figure 9. (a) Spatial distribution of vertical velocity (shading, units: $\mathrm{m} \mathrm{s}^{-1}$ ) at the height of $1 \mathrm{~km}$ at 0430 UTC. (b) Cross sections of the vertical velocity (shading, units: $\mathrm{m} \mathrm{s}^{-1}$ ), the wind field (streamlines), the LCL (gray dotted line), the PBLH (black dotted line), and the LFC (magenta solid line) along the black line in (a). (c) Time series of the sea level pressure at locations denoted by the stars in (a). The NCI, $\mathrm{PCI}$, and MCI represent no convective initiation, plain convective initiation, and mountain convective initiation, respectively. (d) Time-distance plot of vertical velocity (shading, units: $\mathrm{m} \mathrm{s}^{-1}$ ) at the height of $1 \mathrm{~km}$ during the period from 0400 to 0500 UTC. 
In order to examine the influence of the low-level fluctuations in the atmosphere on the initiation of convection, the vertical distribution of divergence, vorticity, and the wind field before and after the initiation of cell ' $a$ ' was analyzed. At 0430 UTC (Figure 10a), the distribution of vorticity and divergence showed a clear positive and negative change below the height of $2 \mathrm{~km}$, and they propagated from west to east. The vorticity was located one-quarter of a wavelength behind the divergence, showing the characteristics of a gravity wave (Li, 1978; Liu et al., 2015) [22,23]. In terms of the wind field, westerly wind dominated above the level of $2 \mathrm{~km}$, while it was controlled by weak easterly wind below the level of $1 \mathrm{~km}$. There were several centers of secondary circulations at the height of $1.5 \mathrm{~km}$. At the triggering position of convective cell ' $\mathrm{a}$ ', strong divergence occurs above $0.5 \mathrm{~km}$ and strong wind convergence occurs below $0.5 \mathrm{~km}$. In the low levels of the left side of the triggering position, the vorticity was negative, corresponding to the downdraft, while the vorticity was positive on the right side, corresponding to the updraft. The convective cell 'a' was not triggered at this moment. After $8 \mathrm{~min}$ (Figure 10b), due to the forward propagation of the wave, the negative vorticity area on the upper left side of the triggering position of cell ' $a$ ' becomes positive vorticity area, which was favorable for upward motion. The convergence center at the surface merged with the newly formed updraft and its left branch first broke through LCL and LFC, and cell ' $a$ ' triggered at the height of $2.3 \mathrm{~km}$. At 0450 UTC (Figure 10c), the wave continued to move forward, and the positive vorticity area at $2 \mathrm{~km}$ above the triggering position of cell 'a' further increased and merged with the vertical movement induced by the convergence at the surface. The updraft completely broke through the LCL and LFC, and the secondary circulation on the right side of cell ' $a$ ' was significantly enhanced.

Figure $10 \mathrm{~d}-\mathrm{f}$ is the same as Figure $10 \mathrm{a}-\mathrm{c}$, but for convective cell ' $b$ '. Similar fluctuations of the atmosphere and weak vertical wind shear existed in the lower levels of the troposphere before and after the triggering of cell ' $b$ ', and its trigger mechanism was similar to that of cell ' $a$ '. Therefore, Figure 10 shows that the surface convergence center caused by the secondary circulation of wind field is the potential triggering area of convective cells in plains, and the propagation of gravity wave is the key. The ascending branch of the secondary circulation is the vertical upward movement of the ageostrophic wind caused by the surface convergence, providing the basis for the triggering of convection in the plain. With the forward propagation of gravity wave, the positive vorticity area connected with ascending branch of a secondary circulation, which easily causes the low-level airflow to break through the LCL and LFC, and trigger convective cells in plains. After that, the strong updraft sinks in the front of convective cell, and enhances the secondary circulation, and the convective cell further develops.

In short, the convective cells in the plains region during the warm-sector precipitation stage were triggered against the background of the eastward movement of the Hetao cyclone. This movement caused the oscillation of the low-level pressure field and triggered a gravity gave that propagated from west to east. In addition, the plains region was controlled by southwesterly wind at $700 \mathrm{hPa}$ and southeasterly wind at the surface, forming a weak east-west wind shear in the vertical direction. Several secondary circulations were generated in the lower levels of the troposphere. Cells were initiated by the combined effect of the low-level gravity wave and the updraft branch of the secondary circulations in the lower troposphere. 

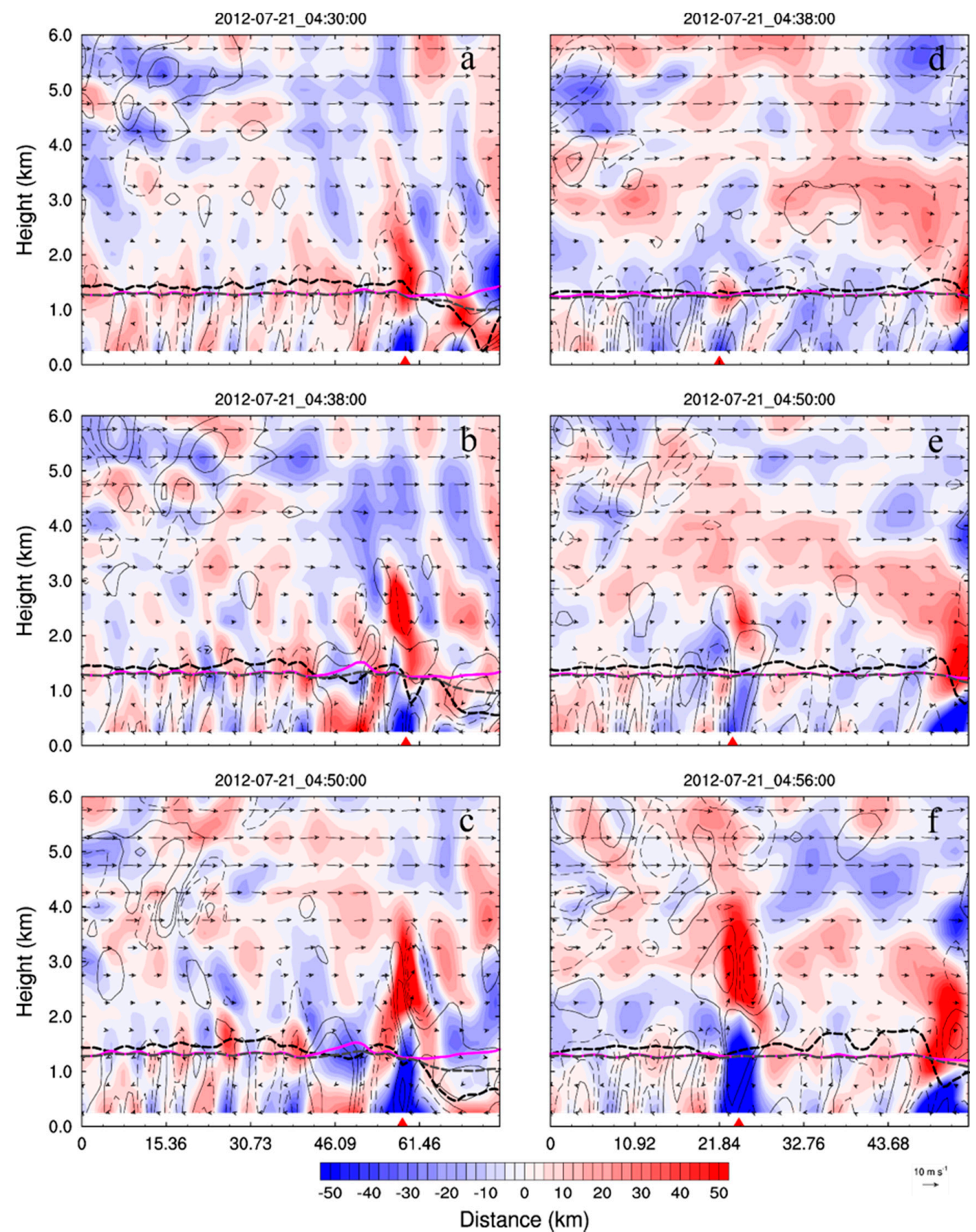

Figure 10. (a-c) Vertical cross sections of the simulated divergence field (shaded, units: $10^{-5} \mathrm{~s}^{-1}$ ), the vorticity field (contoured, units: $10^{-5} \mathrm{~s}^{-1}$ ), the wind field (vectors, units: $\mathrm{m} \mathrm{s}^{-1}$ ), the LCL (gray dotted line), the PBLH (black dotted line), and the LFC (red solid line) during the evolution of convective cell ' $a$ ' over the plains, valid at 0430, 0438, and 0450 UTC 21 July 2012, respectively. (d-f) As in (a-c) but for convective cell ' $b$ ', valid at 0430, 0438, and 0450 UTC 21 July 2012, respectively.

\subsection{Initiation of the Convective Cells over the Mountains}

Observations have shown that more convective cells were initiated over the mountains than the plains during the warm-sector precipitation period. For example, the fourth MCS that passed through Beijing (MCS-D) was initiated from the eastern foot of the Taihang Mountains, and then propagated northeastwards along the Mountains, producing the last heavy precipitation event in Beijing. In this section, the formation processes of the convective cells over the mountains are examined based on the simulation data. Then, the influence of the Hetao cyclone on the triggering of cells is analyzed in detail. Finally, a probable mechanism for the triggering of the convective cells over the mountains is presented. 


\subsubsection{Characteristics of the Initiation Process of MCS-D}

As seen from the observation, the initial cells of MCS-D were formed over the Taihang Mountains, so their horizontal and vertical characteristics were different from MCS-C, which was triggered in the plain region. From Figure 11, the convective cells were initiated over the eastern foot of the Taihang Mountains $\left(38.50^{\circ}-38.50^{\circ} \mathrm{N}, 112.7^{\circ}-113.7^{\circ} \mathrm{E}\right)$, where the terrain height exceeded $1000 \mathrm{~m}$. There was a trumpet-shaped area in the region of $\left(38.50^{\circ} \mathrm{N}, 113.20^{\circ} \mathrm{E}\right)$. At $0200 \mathrm{UTC}$ (Figure $\left.11 \mathrm{a}\right)$, it was controlled by the southwesterly wind at $700 \mathrm{hPa}$, and a convective block (labeled ' $\mathrm{c}^{\prime}$ ) appeared at the inflection point of the windward slope of the trumpet-shaped topography. The intensity of the

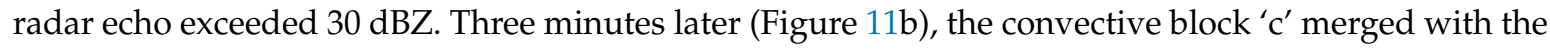
cloud system downstream of it (the northeast side), and formed into a convective cell. Meanwhile, a new block (' $d$ ') was initiated in the upstream of cell ' $c$ ' (the southwest side), with the radar intensity exceeding $20 \mathrm{dBZ}$. At 0207 UTC (Figure 11c), the convective block 'd' merged with the stratiform clouds to its rear, and was enhanced to $35 \mathrm{dBZ}$. After 3 min (Figure 11d), under the guidance of the southwesterly wind, ' $\mathrm{d}$ ' intensified to a convective cell as a result of the orographic uplift on the north side of the trumpet-shaped area. A southwest-northeast wave train of convective cells was formed.
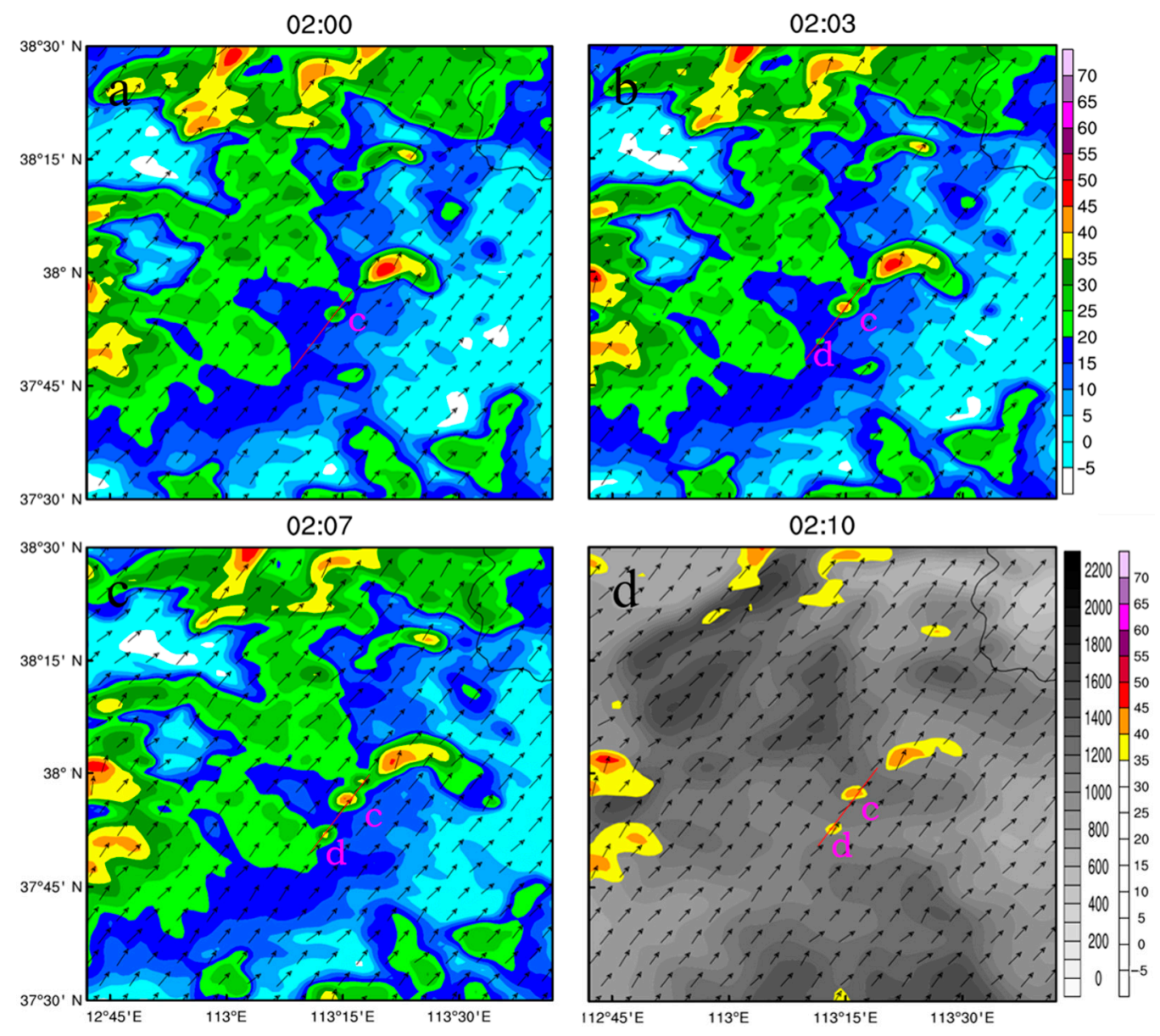

Figure 11. (a-c) Simulated composite radar reflectivity (shaded, units: dBZ) and the wind field (vector arrows, units: $\mathrm{m} \mathrm{s}^{-1}$ ) at $700 \mathrm{hPa}$ at 0200, 0203, and 0207 UTC 21 July 2012, respectively. The letters "c" and " $\mathrm{d}$ " denote convective cells over the mountains. (d) As in $(\mathbf{a}-\mathbf{c})$ but the composite radar reflectivity (color shaded, units: $\geq 35 \mathrm{dBZ}$ ) and the topographic height (gray shaded, units: $\mathrm{m}$ ).

Figure 12 shows a vertical cross section of the radar reflectivity and wind field along the red line in Figure 11. At 0200 UTC (Figure 12a), the terrain height was about $1.2 \mathrm{~km}$, and the core of convective cell ' $c$ ' (>35 dBZ) was at the height of $3.5 \mathrm{~km}$, where the upward motion was strong. In the upstream of 
cell ' $a$ ', a weak convective block ' $d$ ' had just initiated and was located above the LCL (gray dotted line), PBLH (black dotted line), and LFC (pink solid line). Three minutes later (Figure 12b), cell ' $c$ ' intensified significantly, and cell 'd' also enhanced to 15 dBZ. At 0207 UTC (Figure 12c), the radar echoes of cell ' $c$ ' had reached to the ground and cell ' $\mathrm{d}$ ' had started to develop downwards. The corresponding LCLs, LFCs, and PBLHs also increased for the two cells. At 0210 UTC (Figure 12d), the radar echo of cell ' $d$ ' intensified and reached to the ground, and merged with the cloud systems of cell ' $c$ ' because of the effects of the guiding airflow and topography. Therefore, compared with the convective cells triggered over the plains, the initiation of the cells over the mountains was closely related to the topography, and no obvious vertical wind shear existed. In addition, the secondary circulation of the cells in front of them also influenced the formation of these convective cells.
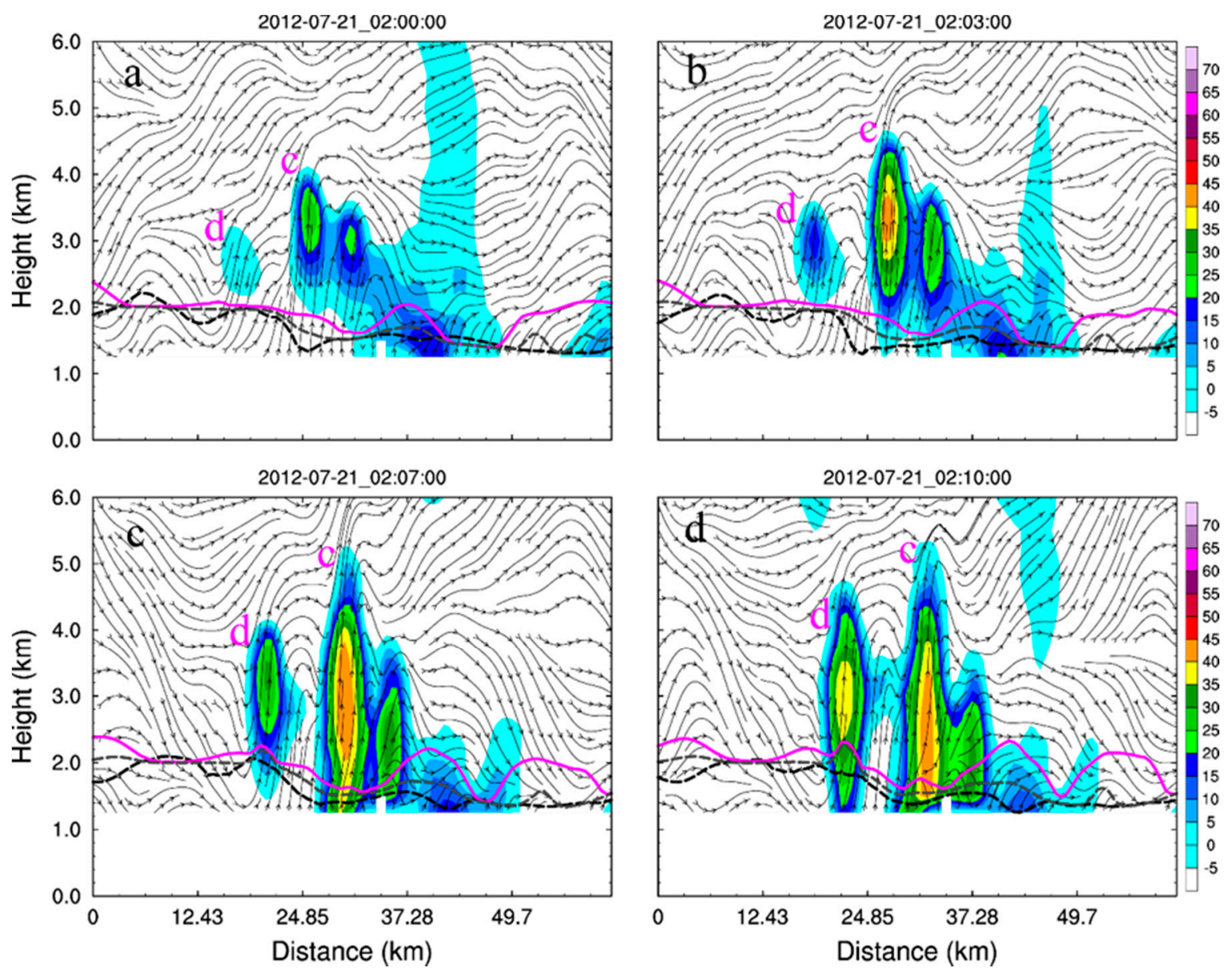

Figure 12. (a-d) Vertical cross sections of the simulated composite radar reflectivity (shaded, units: $\mathrm{dBZ}$ ), the wind field (streamlines, units: $\mathrm{m} \mathrm{s}^{-1}$ ), the LCL (gray dotted line), the PBLH (black dotted line), and the LFC (magenta solid line) along the red lines given in Figure 10, valid at 0200, 0203, 0207, and 0210 UTC 21 July 2012, respectively. The letters " $c$ " and " $d$ " denote convective cells over the mountains.

\subsubsection{Initiation Mechanism of the Convective Cells over the Mountains}

In order to explore the initiation mechanism of the convective systems over the mountains, a comprehensive analysis and diagnosis of the physical quantities was carried out. Figure 13 shows the distribution of the wind field at $10 \mathrm{~m}$ and the centers of the radar echoes at the triggering time of MCS-D. At 0200 UTC (Figure 13a), there were two convergence lines of wind in the convective triggering area. One of them was produced by the convergence of southerly and westerly wind, while the other was related to the confluence of southerly downhill flow and easterly flow at the trumpet-shaped topography. At 0203 UTC (Figure 13b), cell ' $c$ ' was initiated on the topographic convergence line near 
the trumpet-shaped region, and cell ' $\mathrm{d}$ ' was initiated on the south side of the convergence line at 0207 UTC (Figure 13c). Three minutes later (Figure 13d), cell ' $d$ ' moved to the convergence line under the guidance of the southwesterly wind, and a wave train of convective cells was formed together with cell ' $c$ ' and its downstream cells. It should be pointed out that both cell ' $c$ ' and ' $d$ ' were initiated in the crossing region of the two convergence lines, which indicated that the triggering of the convective systems over the mountains may have been related to the two terrain convergence lines.
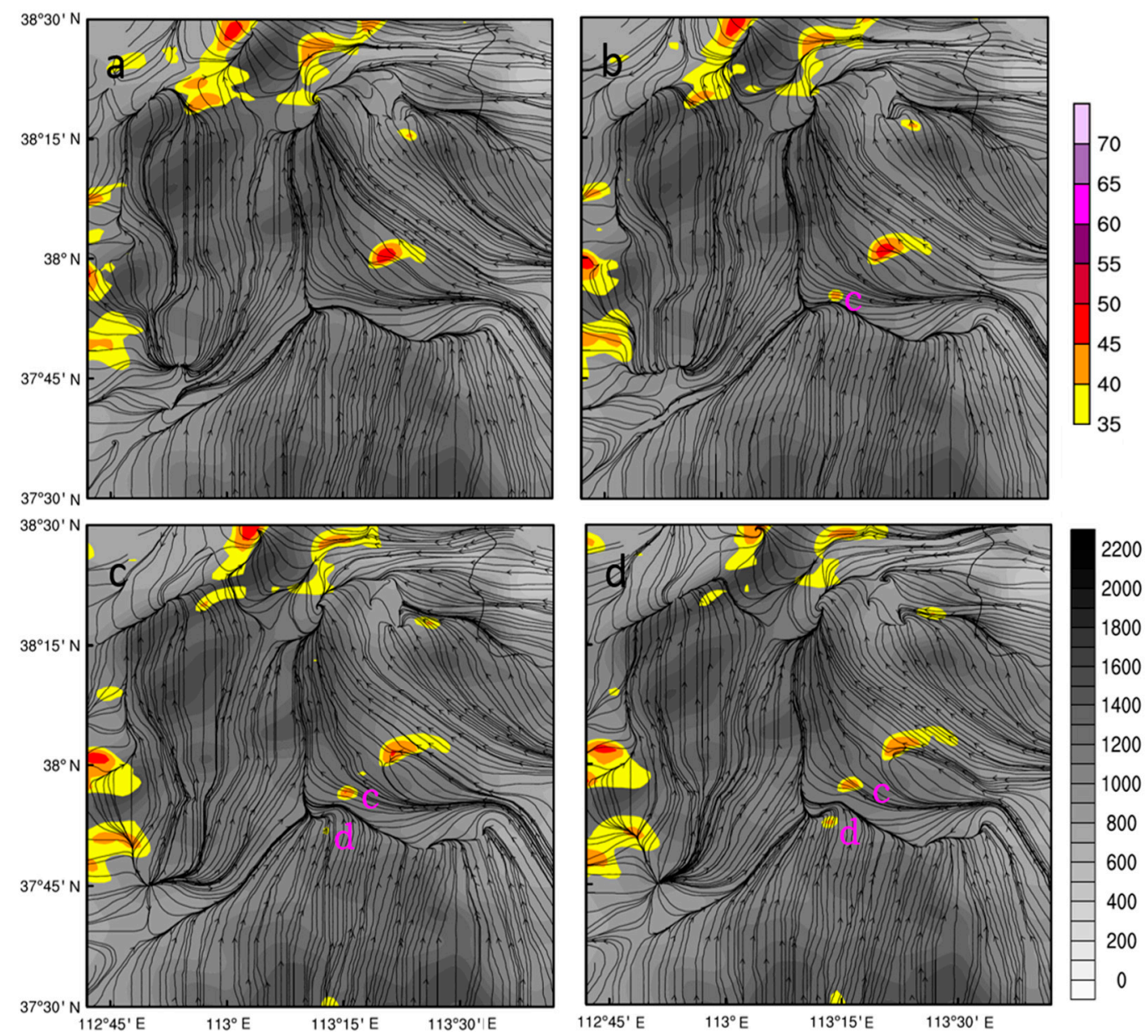

Figure 13. (a-d) Simulated composite radar reflectivity (color shaded, units: $\geq 35 \mathrm{dBZ}$ ), the topographic height (gray shaded, units: $\mathrm{m}$ ), and the 10-m wind field (streamlines) during the evolution of convective cells ' $c$ ' and ' $d$ ' over the mountains at 0200, 0203, 0207, and 0210 UTC, respectively.

In order to better understand the dynamic and thermodynamic characteristics during the initiation of convective cells, the wind field, the skew-T plots and potential temperature perturbation are analyzed together. Figure 14a,b shows wind field at $10 \mathrm{~m}$ and the red arrows indicate the wind speed greater than $5 \mathrm{~m} \mathrm{~s}^{-1}$, while Figure 14c,d shows wind field at $850 \mathrm{hPa}$ and the red arrows indicate the wind speed greater than $12 \mathrm{~m} \mathrm{~s}^{-1}$. It was shown that there existed southeasterly low-level jet near the ground while the southwesterly low-level jet existed at $850 \mathrm{hPa}$. The low-level jet approached the Taihang mountains and led to the formation of convergence line.

Figure 14e,f shows the skew-T plots at 0100 and 0400 UTC, respectively. It was shown that the convective available potential energy (CAPE) was about $687 \mathrm{~J} \mathrm{~kg}^{-1}$ at 0100 UTC and the LCL was about $888 \mathrm{hPa}$. There was vertical shear of wind direction, with southeasterly wind below $1000 \mathrm{hPa}$ and southwesterly wind with the layers above, which was consistent with the wind field in Figure 14a-d. 

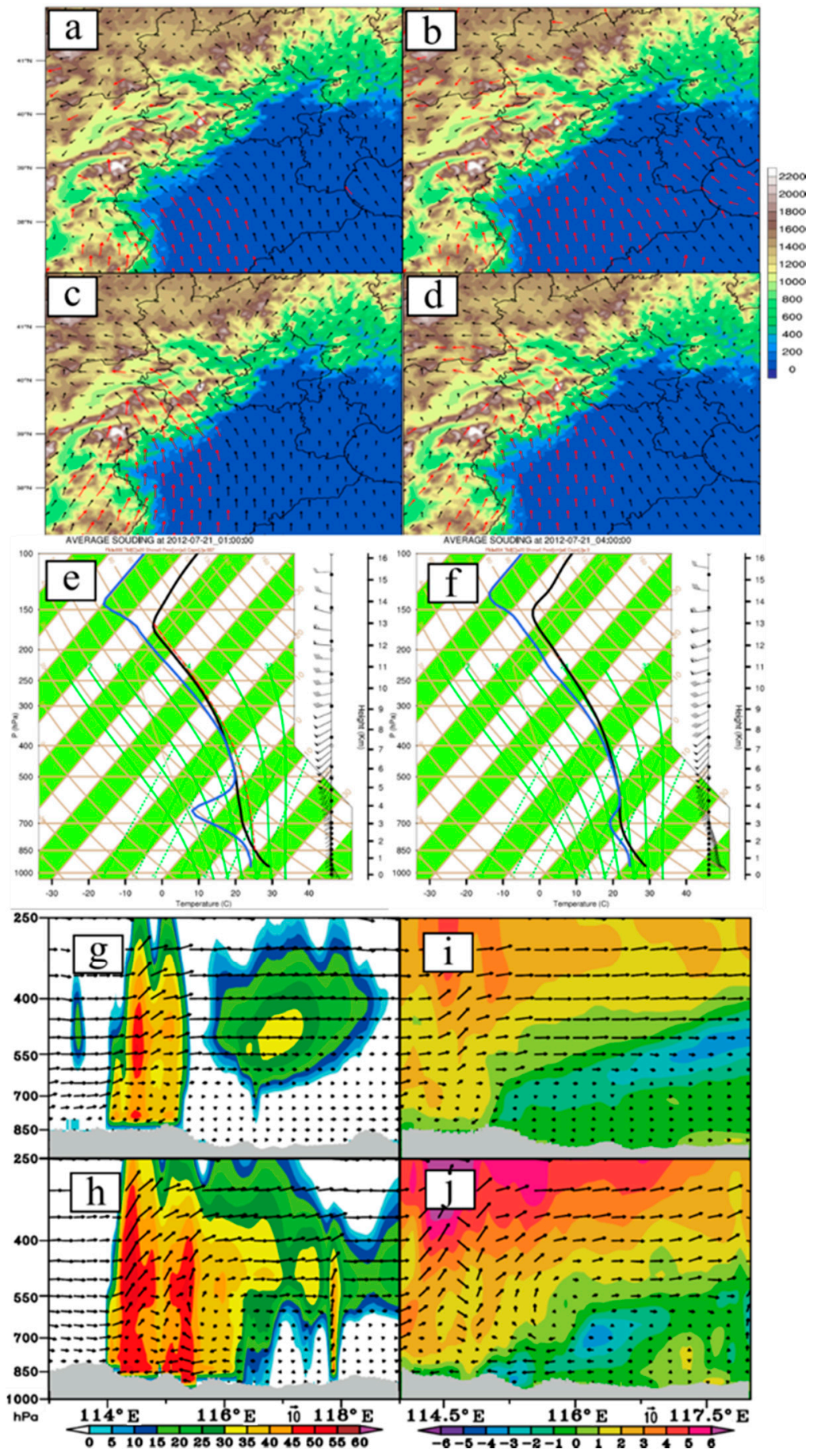

Figure 14. (a,b) Simulated $10 \mathrm{~m}$ horizontal wind (arrow), with red arrows wind speed $>5 \mathrm{~m} \mathrm{~s}^{-1}$. $(\mathbf{c}, \mathbf{d})$ Simulated horizontal wind at $850 \mathrm{hPa}$ (arrow), with red arrows wind speed $>12 \mathrm{~m} \mathrm{~s}^{-1}$. The shading area is terrain height. (a,c) is at $0200 \mathrm{UTC},(\mathbf{b}, \mathbf{d})$ is at $0400 \mathrm{UTC}$. (e,f) Skew-T plots of soundings averaged over the black box in Figure 3a1 at 0100 and 0400 UTC, respectively. Simulated vertical cross sections of $(\mathbf{g}, \mathbf{h})$ radar reflectivity (dBZ, shaded), wind field (vectors), and $(\mathbf{i}, \mathbf{j})$ potential temperature perturbation $\left({ }^{\circ} \mathrm{C}\right.$, shaded) at $(\mathbf{g}, \mathbf{i}) 0800$ and $(\mathbf{h}, \mathbf{j}) 0830 \mathrm{UTC}$, respectively. The gray-shading at the bottom denotes the topography profile.

In order to analyze the cool pool effect, the vertical potential temperature perturbation along the moving direction of the convection cell was analyzed (Figure 14g-j). At $0800 \mathrm{UTC}$, as the convection cell was just initiated the cool pool was not evident at the low levels (Figure 14i). As the cell moved 
forward slightly and intensified at $0830 \mathrm{UTC}$, a mid-level cold center with the intensity below $-4{ }^{\circ} \mathrm{C}$ is formed at around $116.3^{\circ} \mathrm{E}$ (Figure $14 \mathrm{j}$ ), which is probably caused by the evaporative cooling of precipitation. The cold and moist air gradually descends and flows rearward with northeasterly wind near surface. Additionally, they accumulate at around $114.3^{\circ} \mathrm{E}$, forming into a cold pool at the surface. It can be seen that the cold pool extends to the height of $800 \mathrm{hPa}$ with the intensity less than $-3^{\circ} \mathrm{C}$. The enhancement of convections also leads to the strengthening of secondary circulations around the cell. The vertical wind shear increases, and enhances convections and promotes the back-building of the convective cell.

In order to further verify the conclusions drawn from the above discussion, the three-dimensional field of wind and radar echo at the triggering time of the cells is shown in Figure 15. It can be seen that southerly wind dominated on the right-hand side of the surface, which then turned south at the north end and ascended slantwise at the south end, indicating the influence of the Hetao cyclone on the distribution of the wind field near the surface. The southwesterly airflow in the southeastern quadrant of the Hetao cyclone converged with the southwesterly flow at $700 \mathrm{hPa}$, and they ascended along the Taihang Mountains. Owing to the blocking effects of the mountains, airflow converged near the convergence line in Figure 15 and new cells were triggered.

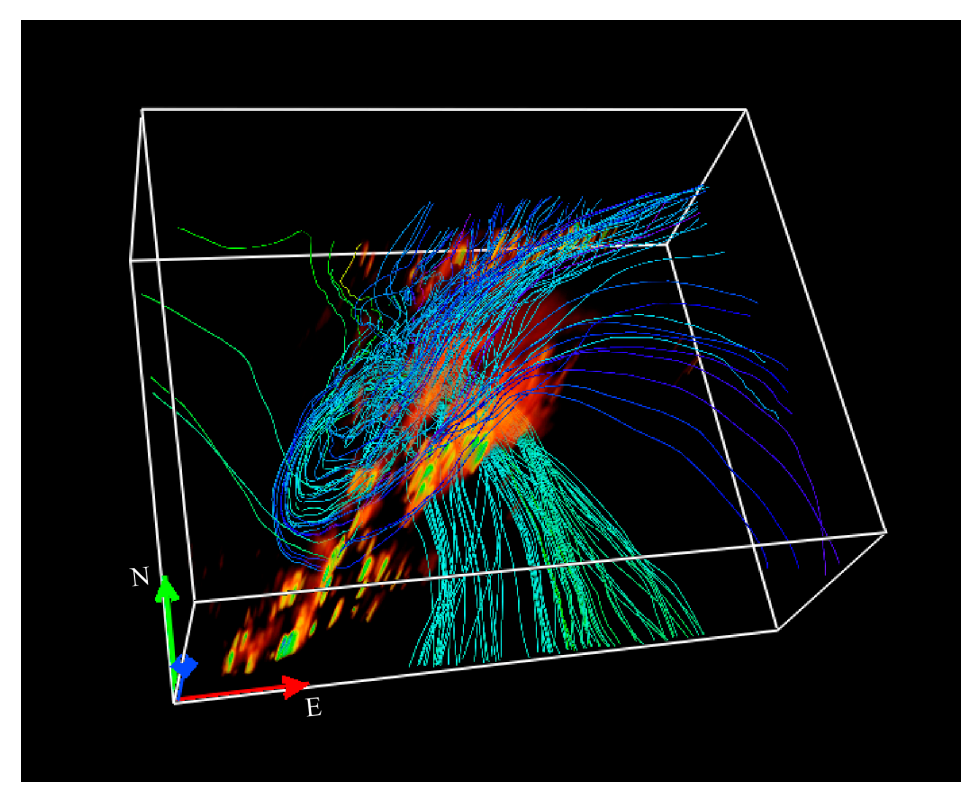

Figure 15. Three-dimensional diagram of flow field (streamlines) and radar echo reflectivity (shaded) at the initiation time of the convective cells over the mountains.

In summary, the convective cells over the mountains were also triggered against the background of the eastward movement of the Hetao cyclone. The airflow in the southeastern quadrant of the Hetao cyclone converged with the southwesterly flow at $700 \mathrm{hPa}$ and formed into a strong southwesterly jet in the low levels of the troposphere. The low-level jet converged with the westerly wind of the cyclone or the easterly wind from the plains, and several convergence lines of wind were formed because of the blocking by the Taihang Mountains. Convective cells were successively triggered by the interaction of the southwesterly jet and topographic convergence line.

\subsection{Organization of the Convective Cells during the Warm-Sector Precipitation}

\subsubsection{Characteristics of the Organizational Processes}

As already mentioned, there were two types of organizational modes of convective systems during the warm-sector precipitation stage in Beijing. One was the echo-scale organization. For example, two meso- $\gamma$-scale convective cells (labeled ' $\mathrm{d} 1^{\prime}$ and ' $\mathrm{d} 2^{\prime}$ ) were located at $113.75^{\circ} \mathrm{E}$ and $38.35^{\circ}$ 
$\mathrm{N}$, respectively, at 0420 UTC 21 July (Figure 16a). A small block of convection ('d3') was situated to their south side. At 0500 UTC (Figure 16b), the convective block 'd3' merged with 'd2' and developed into a meso- $\gamma$-scale cell. Cell ' $\mathrm{d} 2$ ' then merged with cell ' $\mathrm{d} 1$ ' and organized into MCS-D in the future. The other type of organizational mode was wave-scale. It can be seen from Figure $16 \mathrm{~b}$ that two wave trains of convective cells were formed over the Taihang Mountains and the plains to the southeast of the mountains, respectively. They crossed and converged in the southwestern part of Beijing, and resulted in the city's heavy precipitation.
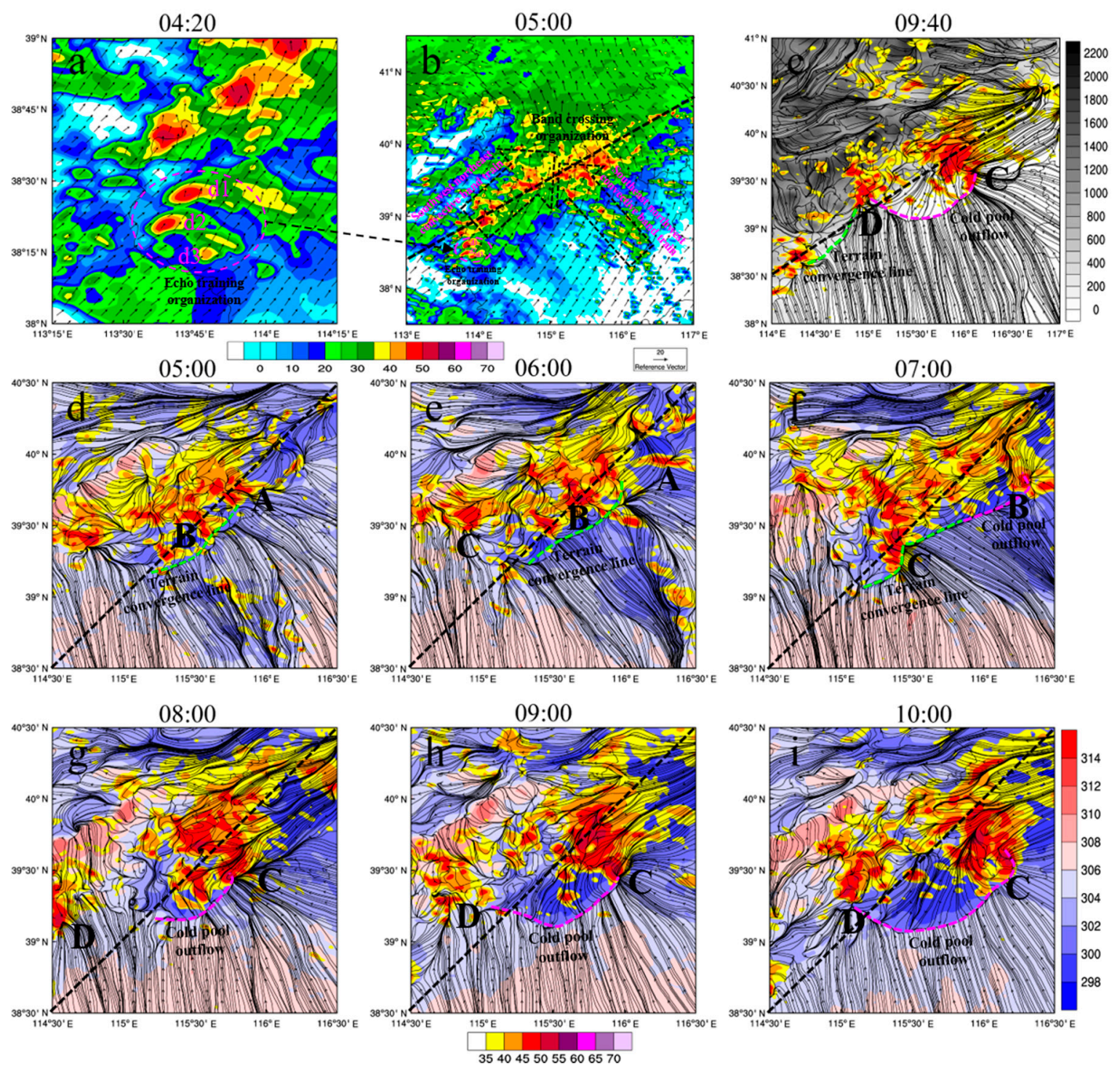

Figure 16. (a,b) Simulated composite radar reflectivity (shaded, units: dBZ) and the wind field (vector arrows, units: $\mathrm{m} \mathrm{s}^{-1}$ ) at $700 \mathrm{hPa}$ at 0420 and 0500 UTC 21 July 2012, respectively. The magenta dotted ellipse in (a) denotes the echo-scale organization, and the two hollow arrows in (b) the band-scale organization. (d-i) Simulated composite radar reflectivity (shaded, units: $\geq 35 \mathrm{dBZ}$ ), the 2-m potential temperature (red and blue shaded, units: $\mathrm{K}$ ) and the 2-m wind field (streamlines) at 0500, 0600, 0700, 0800, 0900, and 1000 UTC, respectively. The letters "A", “B”, " $C$ ", and “ $D$ " represent MCS-A, -B, -C, and $-D$, respectively. (c) As in (d-i) but for the topographic height (gray shaded, units: $m$ ). The green dotted lines denote the terrain convergence line. The magenta dotted line represents the outflow boundary of the surface cold pool. The black dotted lines roughly divide mountains and plains. 
It was found that four convective systems passed through Beijing during the warm-sector precipitation period. The convective systems in the early stage of the precipitation had an important influence on the convective systems in the later stage. At 0500 UTC (Figure 16d), MCS-A and MCS-B were clearly organized, and a weak cold pool was formed at the surface of MCS-B, with a weak outflow boundary on the south side of the cold pool. At 0600 UTC (Figure 16e), MCS-A weakened and moved out of Beijing, while MCS-B strengthened and moved northwards, with a stronger cold pool near the surface. MCS-C had just been initiated at this moment. One hour later (Figure 16f), MCS-B weakened and moved out of Beijing. MCS-C moved above the cold pool and organized into a strong linear convective system. At 0800 UTC (Figure 16g), MCS-C moved to the southwestern part of Beijing and organized into a mature convective system. The intensity of MCS-C in the mature stage was stronger than MCS-B in the same stage. Meanwhile, MCS-D was initiated at this moment. At 0900 UTC (Figure 16h), the cold pool was intensified significantly. MCS-C stayed in situ, with convective cells merging into it successively from the rear. MCS-D moved to the border of the cold pool, with the orographic convergence line on the east side of it and the outflow boundary of the cold pool on the west side of it. At 1000 UTC (Figure 16i), both MCS-C and MCS-D developed further and were well organized. The intensity of the near-surface cold pool also enhanced significantly.

In short, two types of organizational modes existed for the warm-sector convective systems: the convective-scale mode and the wave-scale mode. Convective cells were organized further in the outflow boundary of the cold pool and the orographic convergence lines and new cells were generated at the back edge of the convective system and merged into it.

\subsubsection{Organization Mechanism of Convective Systems during the Warm-Sector Precipitation}

The organization of convective systems during the warm-sector precipitation was closely related to the orographic convergence line at the surface and the outflow boundary of the cold pool. At 0940 UTC (Figure 16c), two convergence lines existed at ground level. The western branch was located in the terrain gradient zone, and was formed because the low-level southerly airflow was blocked by the Taihang Mountains. The eastern branch was located over the plains, and was formed by the convergence of northerly and southerly airflow. Comparing with Figure 16h,i, the eastern branch of the convergence line was the outflow boundary of the cold pool at ground level. At 0900 UTC (Figure 16h), MCS-D was only affected by the orographic convergence line and its intensity was relatively weak. At 1000 UTC (Figure 16i), the outflow of the cold pool intensified, and the boundary moved southwards where it met with the convergence line on the western side, resulting in strong convergence in the local area, which was conducive to the initiation of new cells. MCS-D was intensified and prominently organized when it moved to the strong convergence area.

Figure 17 shows vertical cross sections of the radar reflectivity and potential temperature. At 0930 UTC (Figure 17a1), as cell 'e' developed to its mature stage, a new cell (' $\mathrm{f}$ ') was initiated at the back edge of ' $\mathrm{e}$ '. In view of the potential temperature (Figure 17a2), cell ' $\mathrm{e}$ ' was located above the cold pool, and cell ' $\mathrm{f}$ ' was at the edge of cold pool. Three minutes later (Figure 17b1,b2), cell ' $\mathrm{f}$ ' moved to the cold pool and developed appreciably. Meanwhile, the LCL and LFC of cell ' $f$ ' decreased. Twelve minutes later (Figure 17c1,c2), cell ' $\mathrm{f}$ ' started to merge with the cloud systems in front of it, and new cells were triggered at the boundary of the cold pool. Ten minutes later (Figure 17d1,d2), cell ' $\mathrm{f}$ ' merged completely into MCS-C and the radar echo increased to $45 \mathrm{dBZ}$.

In summary, the eastward movement of the Hetao cyclone enhanced the convergence near the ground over the mountains and plains, which was conducive to the organization of convective systems. New cells were generated at the rear of the convective system, as a result of the outflow boundary of the cold pool and topographic convergence line near the surface. The crossing and convergence of convective wave trains in different directions over the mountains and plains was an important reason for the organization and upscale development of the convective systems. 

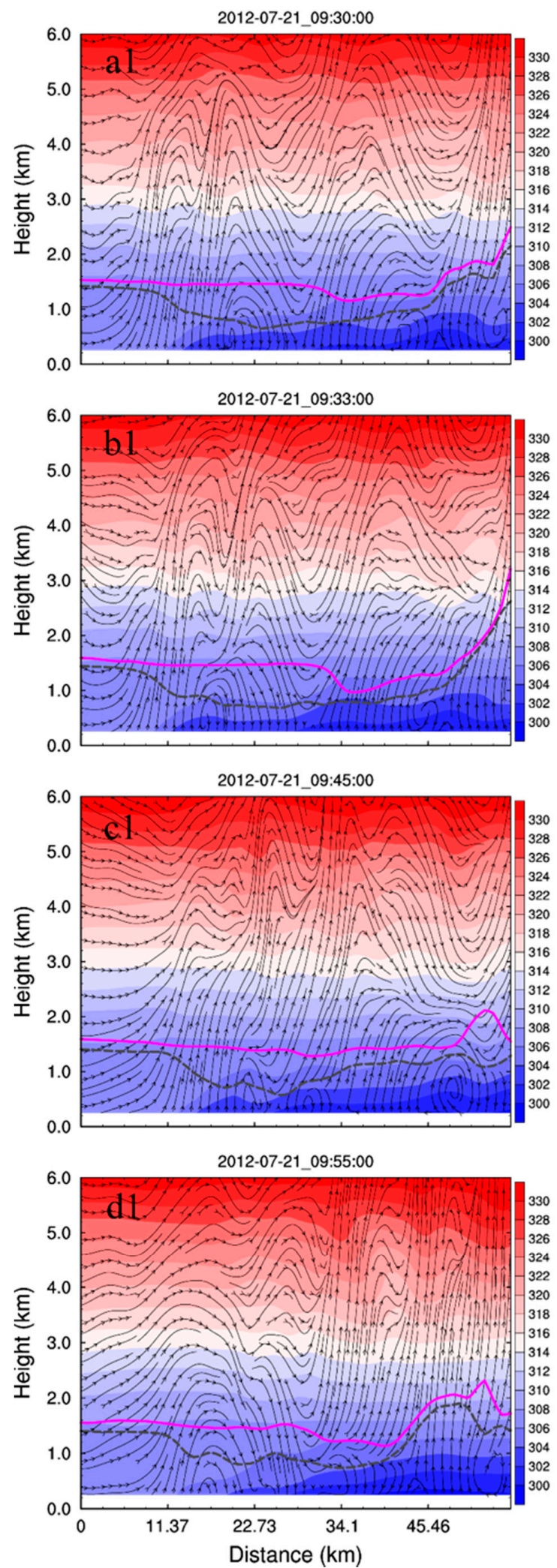

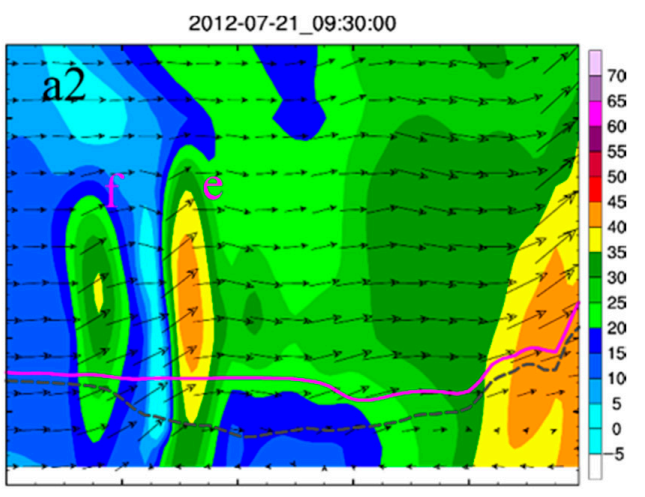

2012-07-21_09:33:00

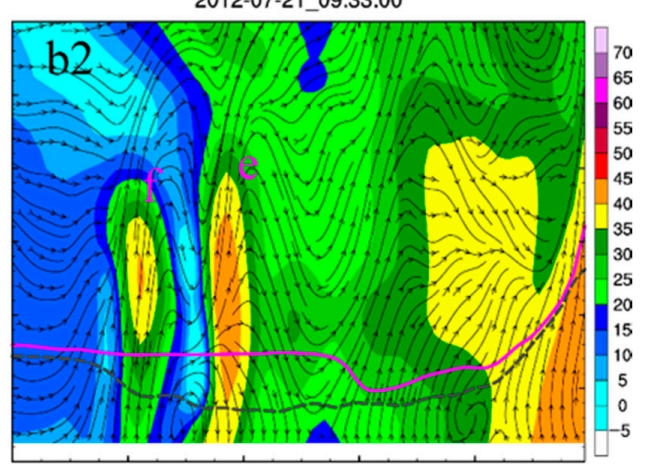

2012-07-21_09:45:00

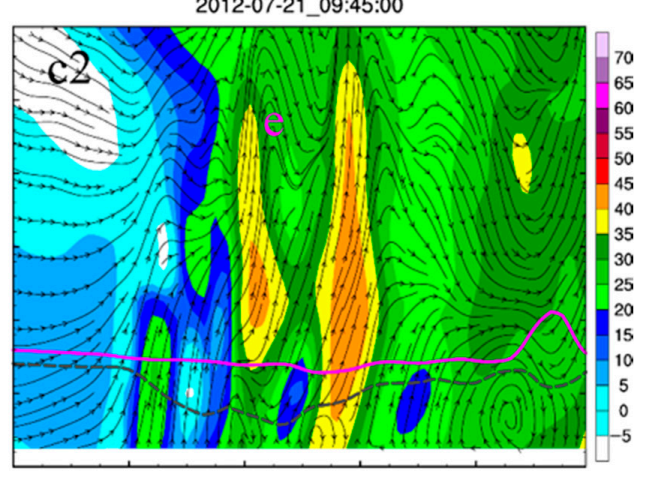

2012-07-21_09:55:00

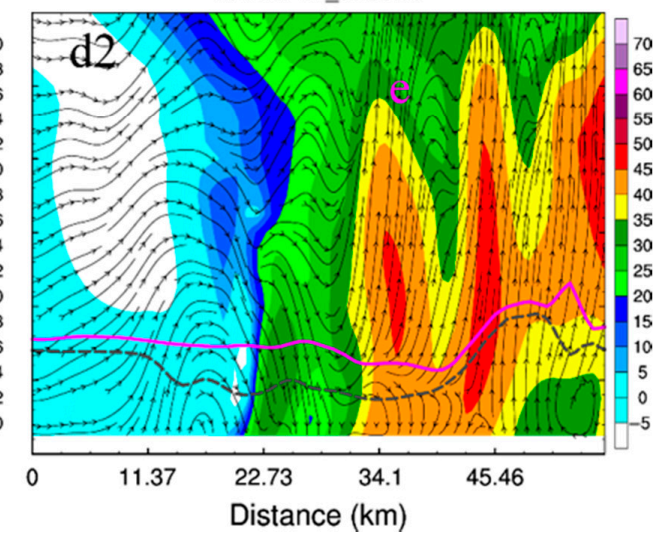

Figure 17. (a1-d1) Vertical cross sections of the simulated equivalent potential temperature (shaded, units: K), the wind field (streamlines, units: $\mathrm{m} \mathrm{s}^{-1}$ ), the LCL (gray dotted line), the PBLH (black dotted line), and the LFC (magenta solid line) during the evolution of convective cells ' $e^{\prime}$ ' and ' $f$ ', valid at 0930, 0933, 0945, and 0955 UTC 21 July 2012, respectively. (a2-d2) As in (a1-d1) but for composite radar reflectivity (shaded, units: dBZ). 
4.4. Conceptual Model of the Initiation and Organization of Convective Systems during the Warm-Sector Precipitation Period

According to the above analysis, a conceptual model of the initiation and organization of the convective systems during this warm-sector precipitation event in Beijing is presented in Figure 18. The convective cells were initiated in the warm-sector region in front of the cold front, as the Hetao cyclone moved eastwards. The Hetao cyclone was initiated from Inner Mongolia and moved eastwards to the Taihang Mountains in southwestern Beijing. The main body of the cyclone was located at the levels of $700-850 \mathrm{hPa}$. On the one hand, the southwesterly airflow at $700 \mathrm{hPa}$ converged with the flow in the southeastern quadrant of the Hetao cyclone, and triggered many convective cells along the topographic convergence line at the eastern foot of the Taihang Mountains. On the other hand, the eastward movement of the Hetao cyclone caused vibration in the pressure field in the lower levels of the troposphere, and triggered a west-east-propagating gravity wave. The gravity wave superimposed on the updraft branch of the secondary circulation of the low-level east-west wind, and new convective cells were triggered over the plains.

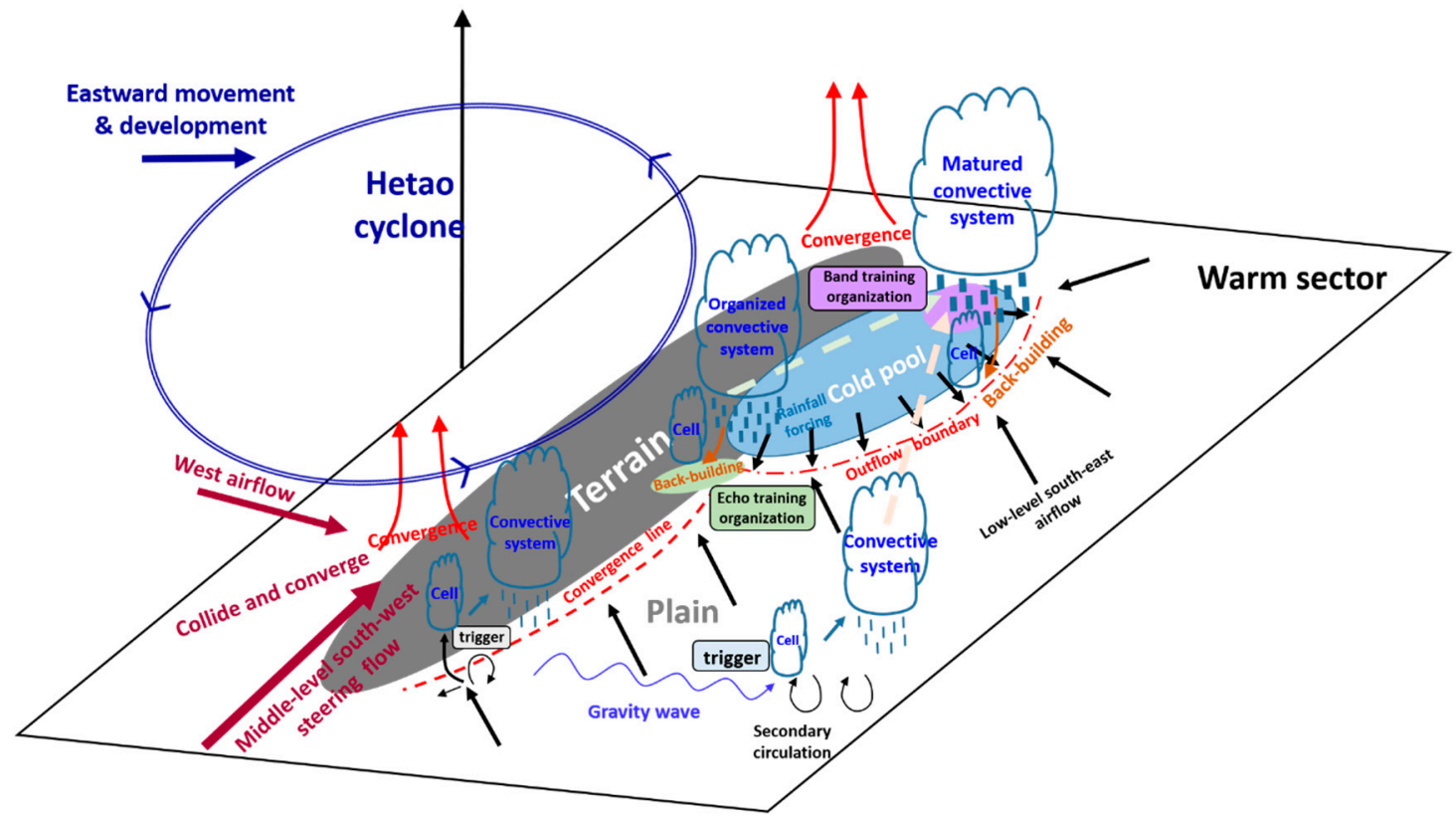

Figure 18. Conceptual model of the probable initiation and organization mechanisms of the mesoscale convective systems in this warm-sector torrential rain event over Beijing.

The organization of the convective systems also occurred against the background of the movement and development of the Hetao cyclone. There were two convergence centers in the southeastern quadrant of the Hetao cyclone, and most of the convective systems were organized and developed around the northern center. During the early stage of the warm-sector precipitation, the convective cells propagated from southwest to northeast along the Taihang Mountains under the guidance of the southwesterly airflow. A near-surface cold pool was formed in the northern convergence center. In the middle to late stage, the cold pool intensified significantly, and the southern branch of the outflow boundary of the cold pool intersected with the northern portion of the topographic convergence line. When the MCS moved to the intersection region, new cells were successively initiated at the back edge of the MCS and then merged into it. The MCS was organized and developed in this way. Meanwhile, the southwest-northeast wave-like convective systems over the mountains and the southeast-northwest convective systems over the plains also intersected in the northern portion of the outflow boundary of the cold pool, where convective systems organized and developed prominently, resulting in the heaviest warm-sector precipitation in southwestern Beijing. 


\section{Conclusions and Discussion}

An extremely torrential rainfall event occurred in Beijing on 21 July 2012, with a record-breaking amount $(460 \mathrm{~mm})$ of rainfall in $18 \mathrm{~h}$. The rainstorm can be divided into two stages: the warm-sector precipitation stage and the cold frontal precipitation stage. The MCSs that produced most of the extreme rainfall were initiated over the mountains and plains, respectively, and developed through convective organization. The convective systems passed through Beijing successively and caused four heavy precipitation processes in the city. In the present paper, the reanalysis data from ECMWF and radar observations were used to analyze the movement and development of a cyclone that initiated in Hetao, Inner Mongolia, which had critical impacts on the occurrence of the warm-sector precipitation in Beijing. Meanwhile, a cloud-resolving simulation by version 4 of the mesoscale WRF model was carried out to reproduce the initiation and organization processes of the convective systems. The main conclusions can be summarized as follows:

1. The Hetao cyclone was a key synoptic system to the warm-sector precipitation in Beijing. (1) The airflow in the southeastern quadrant of the Hetao cyclone converged with the southwesterly flow at $700 \mathrm{hPa}$, and triggered convective cells along the topographic convergence line in the Taihang Mountains. (2) The eastward movement of the Hetao cyclone caused oscillation of the pressure field in the lower troposphere, and triggered a west-east-propagating gravity wave. The gravity wave interacted with the updraft branch of a secondary circulation and triggered convective cells over the plains. (3) Two strong convergence centers formed in the southeastern quadrant of the Hetao cyclone because of the mesoscale disturbance, which was conducive to the initiation and organization of convective systems over the mountains and plains.

2. The initiation and organization of MCSs was reproduced well by the cloud-resolving numerical model. From the simulation results, four convective systems (A, B, C, and D) passed through Beijing from southwest to northeast successively. Among them, MCS-C was the strongest, which was consistent with the observation. Meanwhile, both the observation and simulation showed that MCS-C was formed and organized by two wave-like convective systems, which had different directions.

3. The convective systems were triggered over both the mountains and plains. Thus, the triggering mechanisms were significantly different. Over the mountains, convection was initiated by topographical convergence lines, which were related to the convergence of the airflow in the southeastern quadrant of the Hetao cyclone and the southwesterly airflow at $700 \mathrm{hPa}$. Meanwhile, the easterly wind near the surface accumulated at the eastern foot of the Taihang Mountains. Over the plains, the eastward movement of the Hetao cyclone triggered a strong gravity wave in the low levels, which propagated from west to east and interacted with the updraft branch of the secondary circulation that was produced by the east-west wind shear in the lower troposphere. The wave-like convective systems were triggered in this way.

4. The organization of the convective systems in the warm sector showed upscaling characteristics. In the early stage of the warm-sector precipitation, topographic convergence lines were formed at the eastern foot of the Taihang Mountains because of the southerly wind in the lower troposphere. In the mid-late stage, the outflow boundary of the cold pool near the surface developed southwards. MCS-D developed and organized prominently at the intersection of the topographic convergence line and the outflow boundary of the cold pool. Meanwhile, new cells were triggered along the outflow boundary of the cold pool in the rear of MCS-C, and then merged into it. MCS-C intensified significantly through convective organization. The southwest-northeast wave-like convective systems over the mountains and southeast-northwest wave-like convective systems over the plains converged in the southwestern part of Beijing, and organized further.

In the present paper, the initiation and organization mechanisms of convective systems in the warm sector were examined based on cloud-resolving numerical simulations. However, the simulated convective systems over the plains were weaker than observed. Experiments at finer resolution and the assimilation of more data may be needed in the future to improve the simulation results. It was also revealed that the present numerical model was inadequate in terms of the response to atmospheric 
forcing in the plains area, which may be related to the urban agglomeration and the unique structure of the boundary layer over the plains. In addition, deterministic simulation results were used in this paper. In fact, the initiation and organization processes of convective systems remains highly uncertain. Therefore, ensemble forecasting experiments on the cloud-resolving scale are also needed in the future to further study the predictability of convective systems.

Author Contributions: Conceptualization, F.P., J.M. and X.L.; methodology, F.P., X.L.; software, L.Y.; validation, J.M.; formal analysis, J.M.; investigation, L.Y.; resources, F.P.; data curation, N.W.; writing-original draft preparation, L.Y.; writing-review and editing, J.M., F.P., X.L.; visualization, L.Y., N.W.; supervision, J.M.; project administration, F.P.; funding acquisition, F.P. All authors have read and agreed to the published version of the manuscript.

Funding: This work was supported by the National Key Research and Development Program of China (Grant No. 2018YFC1506801, 2018YFF0300102), the National Natural Science Foundation of China (Grant No. 41405059, 41675059, 41875077), the National Science Foundation for Young Scientists of China (Grant No. 41905048), the Zhejiang Meteorological Science and Technology Project (Grant No. 2020YB06, 2020QN08), and the Zhejiang Province welfare technology applied research project (Grant No. LGF20D05003, 2017C33148).

Conflicts of Interest: The authors declare no conflict of interest.

\section{References}

1. Nozumi, Y.; Arakawa, H. Prefrontal rain bands located in the warm sector of subtropical cyclones over the ocean. J. Geophys. Res. Space Phys. 1968, 73, 487-492. [CrossRef]

2. Kingsmill, D.E.; Neiman, P.J.; Ralph, F.M.; White, A.B. Synoptic and Topographic Variability of Northern California Precipitation Characteristics in Landfalling Winter Storms Observed during CALJET. Mon. Weather Rev. 2006, 134, 2072-2094. [CrossRef]

3. Zhang, D.; Lin, Y.; Zhao, P.; Yu, X.; Wang, S.; Kang, H.; Ding, Y. The Beijing extreme rainfall of 21 July 2012 : "Right results" but for wrong reasons. Geophys. Res. Lett. 2013, 40, 1426-1431. [CrossRef]

4. Wen, Y.; Xue, L.; Li, Y.; Wei, N.; Lu, A. Interaction between Typhoon Vicente (1208) and the western Pacific subtropical high during the Beijing extreme rainfall of 21 July 2012. J. Meteorol. Res. 2015, 29, $293-304$. [CrossRef]

5. Zhong, L.; Mu, R.; Zhang, D.; Zhao, P.; Zhang, Z.; Wang, N. An observational analysis of warm-sector rainfall characteristics associated with the 21 July 2012 Beijing extreme rainfall event. J. Geophys. Res. Atmos. 2015, 120, 3274-3291. [CrossRef]

6. Mao, J.; Ping, F.; Yin, L.; Qiu, X. A Study of Cloud Microphysical Processes Associated With Torrential Rainfall Event Over Beijing. J. Geophys. Res. Atmos. 2018, 123, 8768-8791. [CrossRef]

7. Schumacher, R.S.; Johnson, R.H. Organization and Environmental Properties of Extreme-Rain-Producing Mesoscale Convective Systems. Mon. Weather Rev. 2005, 133, 961-976. [CrossRef]

8. Zhong, W.; Zhang, D. An Eigenfrequency Analysis of Mixed Rossby-Gravity Waves on Barotropic Vortices. J. Atmos. Sci. 2014, 71, 2186-2203. [CrossRef]

9. Kim, Y.; Maki, M.; Lee, D.-I.; Jeong, J.; You, C.-H. Three-dimensional analysis of the initial stage of convective precipitation using an operational X-band polarimetric radar network. Atmos. Res. 2019, 225, 45-57. [CrossRef]

10. Browning, K.A.; Hill, F.F.; Pardoe, C.W. Structure and mechanism of precipitation and the effect of orography in a wintertime warm sector. Q. J. R. Meteorol. Soc. 1974, 100, 309-330. [CrossRef]

11. Maddox, R.A.; Chappell, C.F.; Hoxit, L.R. Synoptic and Meso- $\alpha$ Scale Aspects of Flash Flood Events1. Bull. Am. Meteorol. Soc. 1979, 60, 115-123. [CrossRef]

12. Xu, W.; Zipser, E.J.; Chen, Y.-L.; Liu, C.; Liou, Y.-C.; Lee, W.-C.; Jou, B.J.-D. An Orography-Associated Extreme Rainfall Event during TiMREX: Initiation, Storm Evolution, and Maintenance. Mon. Weather Rev. 2012, 140, 2555-2574. [CrossRef]

13. Wang, H.; Luo, Y.; Jou, B.J.-D. Initiation, maintenance, and properties of convection in an extreme rainfall event during SCMREX: Observational analysis. J. Geophys. Res. Atmos. 2014, 119, 13-206. [CrossRef]

14. Su, T.; Zhai, G. The Role of Convectively Generated Gravity Waves on Convective Initiation: A Case Study. Mon. Weather Rev. 2017, 145, 335-359. [CrossRef] 
15. Schumacher, R.S.; Johnson, R.H. Mesoscale Processes Contributing to Extreme Rainfall in a Midlatitude Warm-Season Flash Flood. Mon. Weather Rev. 2008, 136, 3964-3986. [CrossRef]

16. Schumacher, R.S.; Johnson, R.H. Quasi-Stationary, Extreme-Rain-Producing Convective Systems Associated with Midlevel Cyclonic Circulations. Weather Forecast. 2009, 24, 555-574. [CrossRef]

17. Xu, X.; Xue, M.; Wang, Y.; Huang, H. Mechanisms of secondary convection within a Mei-Yu frontal mesoscale convective system in eastern China. J. Geophys. Res. Atmos. 2017, 122, 47-64. [CrossRef]

18. Wang, Y.; Qin, J.; Zhu, L. The Okhotsk-Japan Circulation Pattern and the Heavy Rainfall in Beijing in 2012 Summer. Adv. Meteorol. 2015, 2015, 1-10. [CrossRef]

19. Mao, J.; Ping, F.; Li, X.; Yin, L. Differences in precipitation efficiency and their probable mechanisms between the warm sector and cold front stages of a heavy rainfall event over Beijing. Atmos. Sci. Lett. 2018, 19, e802. [CrossRef]

20. Yu, X. Investigation of Beijing extreme flooding event on 21 July 2012. Meteorol. Mon. 2012, 38, 1313-1328.

21. Barnes, S. Mesoscale objective map analysis using weighted time series observations. NOAA Tech Memo NSSL 1973, 62-68.

22. Li, M. The role of gravity wave in torrential rain. Chin. J. Atmos. Sci. 1978, 2, 201-209.

23. Liu, L.; Ran, L.; Sun, X. Analysis of the structure and propagation of a simulated squall line on 14 June 2009. Adv. Atmos. Sci. 2015, 32, 1049-1062. [CrossRef]

(C) 2020 by the authors. Licensee MDPI, Basel, Switzerland. This article is an open access article distributed under the terms and conditions of the Creative Commons Attribution (CC BY) license (http://creativecommons.org/licenses/by/4.0/). 